\title{
INTERPRETING SILICON ISOTOPES IN THE CRITICAL ZONE
}

\author{
PATRICK J. FRINGS*,+,†, MARCUS OELZE*,+†, FRANZISKA SCHUBRING*, \\ DANIEL A. FRICK*, and FRIEDHELM VON BLANCKENBURG****
}

\begin{abstract}
Metal and metalloid stable isotope ratios have emerged as potentially powerful proxies for weathering, element cycling and export in the Critical Zone. The simplest possible interpretative framework for these isotope ratios has three parameters: (i) the isotope ratio of the parent minerals undergoing weathering, (ii) the partitioning of the element between solute and the new secondary phases, and (iii) the fractionation factors associated with the formation of new secondary phases. Using the example of silicon, we show how all three of these parameters vary along a gradient of erosion rate and regolith residence time defined by three sites located on granitoid bedrock. These sites run from the kinetically limited Rhone Valley in the Central Swiss Alps to the tectonically inactive and supply-limited Sri Lankan highlands, with the Sierra Nevada mountains as a site of intermediate weathering intensity. At each site, primary mineral specific ${ }^{30} \mathrm{Si} /{ }^{28} \mathrm{Si}$ ratios span $>0.4 \%$. These minerals weather differentially, such that the isotope ratio of silicon solubilised from rock differs at the three sites and is not necessarily equal to bulk bedrock composition. The partitioning of silicon between secondary clay and solute is reflected in the clay mineralogy and chemical composition: more intense weathering produces $\mathrm{Si}$ poor clays. The clay composition thus comprises a first-order mass-balance control on the extent to which any fractionation factor can be expressed. Finally, the Si isotope fractionation factor associated with clay formation varies systematically with clay mineralogy: the formation of Si-deplete clay minerals is associated with larger fractionation factors. The magnitude of the fractionation may be mechanistically linked to relative aluminium availability. These findings provide the framework needed to use $\mathrm{Si}$ isotope ratios as a quantitative proxy to explore $\mathrm{Si}$ cycling and reconstruct weathering in the present and past.
\end{abstract} clays

Key words: silicon isotopes, weathering, Critical Zone, isotope fractionation,

\section{INTRODUCTION}

The Critical Zone is the layer of the Earth's skin from treetops to the bottom of groundwater (Brantley and others, 2007), where meteoric fluids interact with rock. The structure and functioning of the Critical Zone is governed by the interplay between the tectonic supply of rock to the Earth's surface, chemical weathering and physical erosion that act to remove material, and biological activity. All three are related to climate, and their interactions define a series of non-linear, competing and often non-intuitive feedback loops (Frings and Buss, 2019). The complexity of the Critical Zone means there is considerable interest in generating geochemical tools that can clarify aspects of these interactions. The isotope ratios of the metal and metalloid elements have emerged as promising candidates. They are often sensitive to one or more of the fluxes that define elemental cycles at the Earth's surface. This sensitivity results from isotope fractionation, the preferential inclusion of one isotope relative to another, during a geochemical process. Of these elements, silicon $(\mathrm{Si})$ is among the best studied (De La Rocha and others, 2000; Ziegler and others, 2005a; Ziegler and others, 2005b; Frings and others, 2016). The cumulative results from two decades

* GFZ German Research Centre for Geosciences, Section Earth Surface Geochemistry, Telegrafenberg, 14473 Potsdam, Germany

** Institute of Geological Sciences, Freie Universität Berlin, 12249 Berlin, Germany

${ }^{\dagger}$ Corresponding author: patrick.frings@gfz-potsdam.de

${ }^{\dagger+}$ These authors contributed equally to this paper. 
of work have yielded insight into $\mathrm{Si}$ isotope distributions in the Critical Zone, but the exact processes governing the $\mathrm{Si}$ isotope partitioning remain to be quantitatively and mechanistically understood.

When $\mathrm{Si}$ is solubilized (that is, weathered) from primary minerals, it has essentially two possible fates: it can be incorporated into a secondary, solid phase, or it can leave the weathering zone as dissolved Si. The secondary phases can be both biogenic (including plant silica bodies termed phytoliths) and abiogenic (secondary oxides and aluminosilicates, including clay minerals). The formation of phytoliths, oxides, and clays are associated with similar $\mathrm{Si}$ isotope fractionations, which tend to favour the inclusion of the lighter ${ }^{28} \mathrm{Si}$ in the new solid, leaving the residual dissolved Si enriched in the heavier ${ }^{30} \mathrm{Si}$ (De La Rocha and others, 2000; Hughes and others, 2013; Frings and others, 2015). The simplest framework for interpreting Si stable isotope ratios views the whole weathering zone as a homogenous reactor operating at steady-state and predicts isotope ratios as a function of element partitioning between two phases. For $\mathrm{Si}$, this model is:

$$
\begin{gathered}
\delta^{30} \mathrm{Si}_{\text {residual }}=\delta^{30} \mathrm{Si}_{\text {initial }}-\varepsilon\left(1-f_{S i}\right) \\
\delta^{30} \mathrm{Si}_{\text {product }}=\delta^{30} \mathrm{Si}_{\text {initial }}+\varepsilon f_{S i}
\end{gathered}
$$

where $\delta^{30} \mathrm{Si}$ is the ${ }^{30} \mathrm{Si} /{ }^{28} \mathrm{Si}$ ratio expressed as a permil deviation from the standard NBS28, $f_{S i}$ is the fraction of reactant converted to product (for example, dissolved $\mathrm{Si}$ in soil solution precipitated as a secondary aluminosilicate or into plant material), $\varepsilon$ is the isotope fractionation associated with that conversion, and the subscripts initial, residual, and product refer to isotope ratios of an unaltered reactant phase, the remaining reactant, and the newly formed phase, respectively. We follow Coplen (2011) in using the term isotope fractionation $\varepsilon$ as a representation of the isotope fractionation factor $\alpha$, that is, $\varepsilon=\alpha-1$ expressed in permil. The model behaviour is shown graphically in figure 1 and can apply to simple closed systems at equilibrium, and open systems at steady state. This framework lies at the heart of the model presented by Bouchez and others (2013), who treat the weathering zone as a well-mixed flowthrough reactor at steady state, such that input and output fluxes balance and do not vary with time. This framework suggests that there are three key parameters that set isotope ratios in the weathering zone: the parent material (that is, $\delta^{30} S i_{\text {initial }}$ ), the stoichiometry (that is, $f_{S i}$ ), and the fractionation (that is, $\varepsilon$ ).

This means that if we want to use $\mathrm{Si}$ isotopes as tracers of Earth surface processes, we need to understand how $\mathrm{Si}$ partitions between solution and secondary phases, and how its isotopes fractionate while doing so. For example, the relative importance of secondary clay minerals and phytoliths is still debated (Engstrom and others, 2010). Recent experimental work challenges the assumption that fractionation factors can be simplified to single, universally applicable values (Oelze and others, 2014; Roerdink and others, 2015). Empirical calibration of these terms along natural gradients is a powerful approach: examples of previous work include the investigation of Si isotope systematics along a soil chronosequence in California (White and others, 2012), or along a rainfall gradient in Hawaii (Bern and others, 2010). Our approach is to develop $\mathrm{Si}$ isotope budgets for sites with different weathering regimes as set by erosion rate, falling along what we term an 'erodosequence'.

Much of the Earth surface is sloping and thus eroding, so erosion rate is an important variable that governs landscape form and evolution. This means that material spends a finite time as regolith before being exported. This underpins the geochemical classification of weathering zones into supply and kinetically limited systems. Settings where material residence time is much longer than the time needed for 


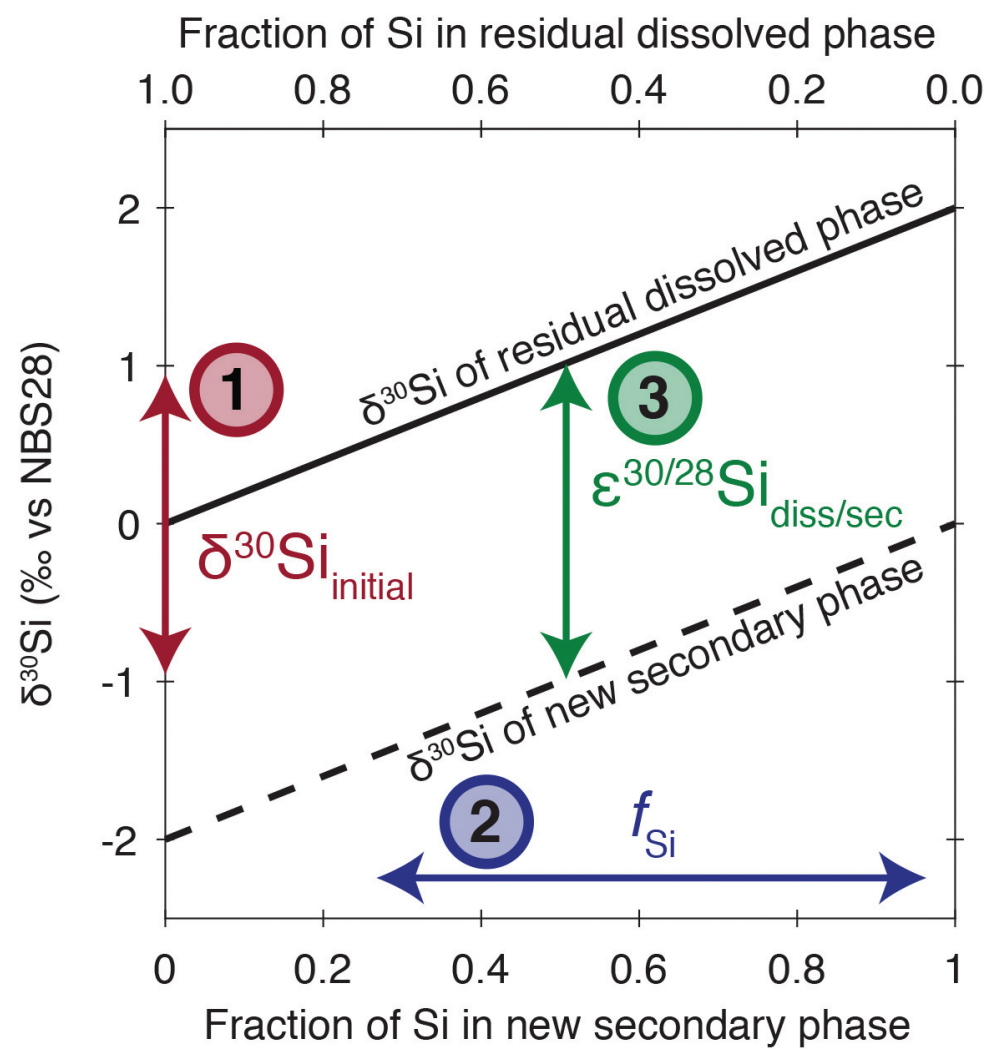

Fig. 1. Schematic of the 'batch-reactor' model for predicting the evolution of isotope ratios as a function of reactant utilisation $f_{S i}$ as a new clay mineral is formed. In this simplified illustration, three independent terms govern the measured $\delta^{30} \mathrm{Si}$ of both the clay and the residual dissolved $\mathrm{Si}$ : (1) the initial ${ }^{30} \mathrm{Si}_{\text {initial }}$ of the dissolved $\mathrm{Si}$, shown here to be zero, (2) the fractionation $\varepsilon^{30 / 28} \mathrm{Si}_{\mathrm{diss} / \mathrm{sec}}$ (termed $\varepsilon_{\text {prec }}$ in this manuscript) for the formation of a clay mineral from a soil-water solution, shown here to be $-2 \%$ (that is, the fractionation factor $\alpha=0.998$ ), and (3) the reaction utilisation $f_{S i}$ (termed $f_{s e c}^{S i}$ in this manuscript). All three may be linked to the weathering regime at a given site. Typically, $f_{\mathrm{Si}}$ is the parameter of interest since this contains geologically relevant information; it cannot be interpreted directly from a measured isotope ratio without knowledge of the other two parameters.

primary minerals to dissolve represent a supply-limited endmember. Conversely, settings where minerals pass through the weathering zone much quicker than they can dissolve represent a kinetically limited endmember (Stallard and Edmond, 1983; Dixon and others, 2012). These are typically, but not necessarily, associated with low and high denudation rates, respectively. This division has predictive power: weathering rates at supply-limited sites should not correlate with climate, while those of kinetically limited sites should. This is largely borne out by the available data (for example, West and others, 2005). It also explains the presence of a weathering 'speed limit' (Dixon and von Blanckenburg, 2012; Larsen and others, 2014; Maher and Chamberlain, 2014), set by the mineral solubilities and dissolution kinetics at Earth surface conditions. It can reasonably be expected that the weathering regime influences how metal(loid) isotope ratios vary, by governing the dissolution of primary minerals and the formation of secondary phases. The key benefit of eroding sites is that at steady-state, mass-balance framework centred around equation (1) and equation (2) can be applied. An 'erodosequence' - a series of sites along a gradient in erosion rate 
and residence time - is thus a promising means to advance our understanding of novel metal isotope geochemistry.

Our erodosequence sites define a gradient of weathering intensity. Defined as $W / D$, the fraction of total denudation $D$ performed by chemical weathering $W$ (Bouchez and others, 2014), we use weathering intensity as an index of weathering regime. Thus, $W / D=0$ would be a completely kinetically limited site, and $W / D=1$ a supply limited site, though in reality almost nowhere on the globe falls at these extremes. The sites overlie similar granitoid lithologies, but differ in erosion rate, and thus soil thickness and time that material spends in the weathering zone. In this contribution, we assess how each of the three parameters in figure 1 vary along the erodosequence. We show how all three ( $\mathrm{Si}$ isotope ratios of an 'initial' solution, the partitioning of $\mathrm{Si}$ between secondary phases and solutes, and Si isotope fractionation factors associated with formation of secondary phases) appear to vary systematically along the erodosequence, opening the door to the use of $\mathrm{Si}$ isotopes as a quantitative weathering proxy. While specific to silicon isotopes, these interpretations are broadly applicable to many of the 'novel' isotope systems currently being used or developed for Critical Zone studies.

STUDY SITES: THE ALPS-SIERRA NEVADA-SRI LANKA ERODOSEQUENCE

Three sites define the gradient of weathering intensity (fig. 2): a rapidly uplifting and poorly weathered site in the central Swiss Alps that represents a site towards the kinetic limitation end of the intensity spectrum, an intermediate weathering intensity site in the Californian Sierra Nevada, and the highly weathered, tectonically quiescent Sri Lanka highlands representing supply-limited conditions. At all sites, samples derive from weathering profiles spanning from unaltered bedrock to soil surface. They are supplemented with vegetation collected in the immediate vicinity and stream-water samples from the enclosing watershed, or one nearby. All three sites have been described elsewhere (Dixon and others, 2009; Norton and von Blanckenburg, 2010; Hewawasam and others, 2013), and a full overview of site characteristics, sampling, element fluxes, and extensive background data is given by von Blanckenburg and others (2021). Here, we provide only the basic details.

\section{Alps}

Six soil profiles were sampled on a sloping soil-mantled ridgetop of the Honegger Horn at $2565 \mathrm{~m}$ altitude on the northern site of the upper Rhone valley (Goms; fig. 2A) and have previously been described by Norton and von Blanckenburg (2010) and Norton and others (2010). The bedrock is part of the Aare Massif and is composed of foliated gneiss (23\% quartz, $53 \%$ plagioclase, $17 \%$ orthoclase, $4 \%$ biotite and $3 \%$ muscovite) and granite (34\% quartz, $35 \%$ plagioclase, $27 \%$ orthoclase, $4 \%$ biotite). A nearby meteorological station at 1345 masl gives MAT and MAP of $3.1^{\circ} \mathrm{C}$ and $1137 \mathrm{~mm} \mathrm{yr}^{-1}$, respectively. Soils at the site are thin $(<50 \mathrm{~cm})$ and not underlain by saprolite (defined as immobile but weathered rock) to a considerable degree. Vegetation cover is mainly grass species. An average in-situ ${ }^{10} \mathrm{Be}$ derived denudation rate for the soils is $103 \mathrm{t} \mathrm{km}^{-2}$ $\mathrm{yr}^{-1}$ (38 $\mathrm{mm} \mathrm{kyr}^{-1}$, assuming a bedrock density of $2.7 \mathrm{~g} \mathrm{~cm}^{-3}$ ) (Norton and others, 2010). In the soil, the Chemical Depletion Fraction (CDF), a zirconium-based index of fraction of mass loss by chemical weathering, averages 0.31 (Norton and von Blanckenburg, 2010). Accordingly, chemical weathering rates are $c a .32 \mathrm{t} \mathrm{km}^{-2} \mathrm{yr}^{-1}$ and erosion rates $71 \mathrm{t} \mathrm{km}^{-2} \mathrm{yr}^{-1}$. Total regolith thickness is $<50 \mathrm{~cm}$, producing a regolith residence time of 10 kyrs. 

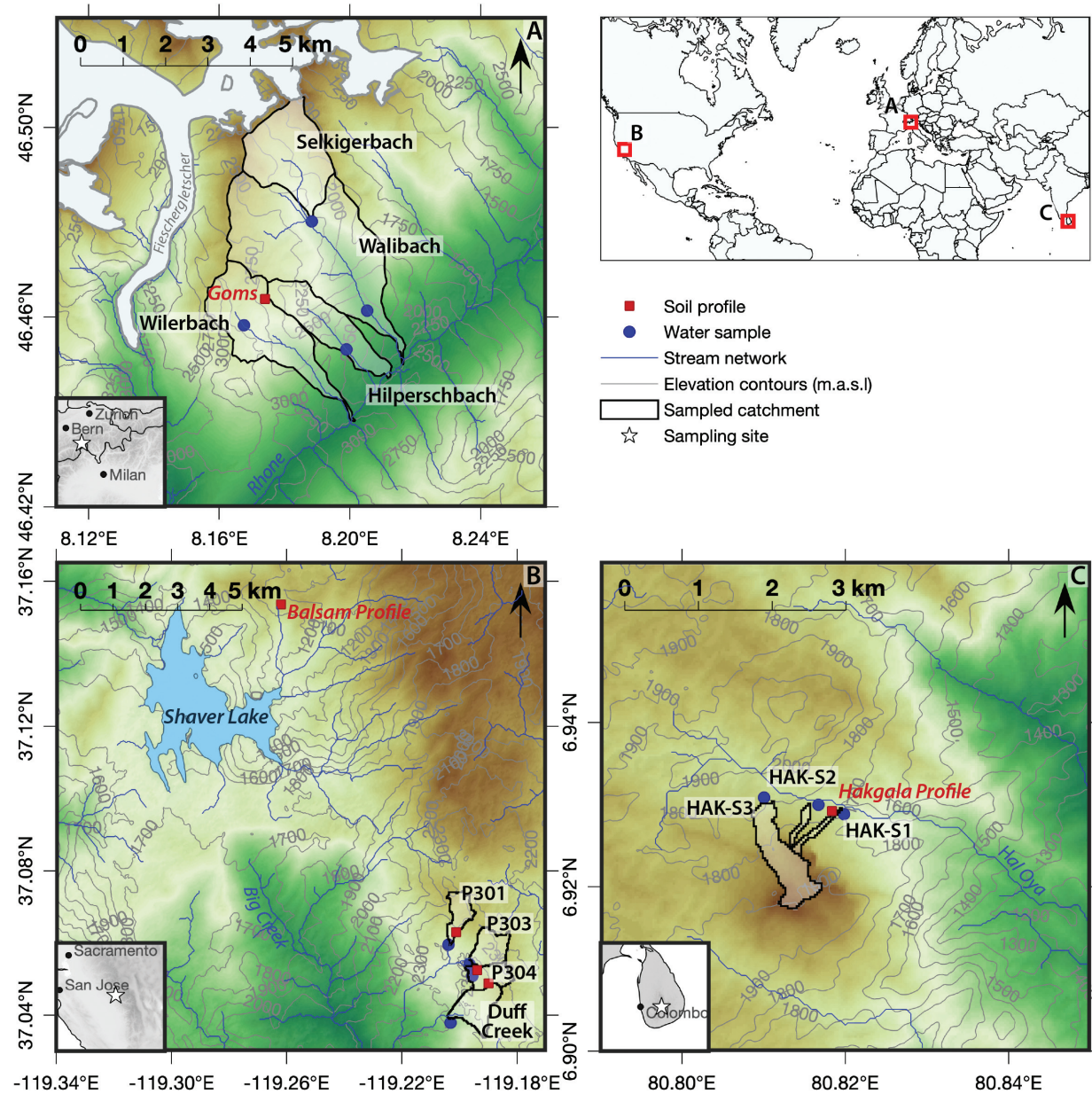

- Soil profile

- Water sample Stream network

Elevation contours (m.a.s.l)

$\square$ Sampled catchment

its Sampling site

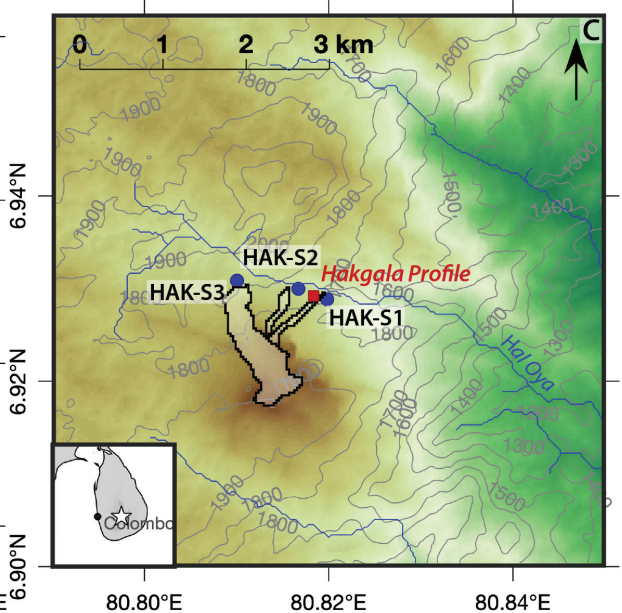

Fig. 2. Locations of the three study sites defining our 'erodosequence', and specific sampling sites. A: Alps; B. Sierra Nevada; C. Sri Lanka. More details about the erodosequence in general are given in the main text and in von Blanckenburg and others (2021), and (amongst others) in Norton and von Blanckenburg (2010) for the Alps, Uhlig and others (2017) for Sierra Nevada, and Hewawasam and others (2013) for Sri Lanka.

\section{Sierra Nevada}

Three soil profiles and one complete regolith profile were sampled in the Californian Sierra Nevada mountain range (fig. 2B). Detailed site descriptions can be found elsewhere (Bales and others, 2011; Johnson and others, 2011; Hunsaker and Neary, 2012; Liu and others, 2013). The soil profiles are located in the Providence Creek (PC) sub-catchments of the Southern Sierra Critical Zone Observatory (CZO) P301, P303, and P304. Bedrock is dominated by the Dinky Creek Granodiorite, a medium grained, equigranular and strongly foliated biotite-hornblende granodiorite/tonalite with sphene, plagioclase and opaque minerals (Bateman and Wones, 1972). It contains abundant disc-shaped mafic inclusions and a quartz rich diorite is also present. MAT is $8.9^{\circ} \mathrm{C}$ and MAP is $920 \mathrm{~mm}$ (Hunsaker and Neary, 2012; Liu and others, 2013). The thickest soil profile is $120 \mathrm{~cm}$ deep. The soils are characterised by a coarseloamy, mixed soil, with an organic rich surface layer. Dixon and others (2009) report that PC soils overlie saprolite of $\geq 10 \mathrm{~m}$ thickness. The vegetation cover consists mainly 
of mixed conifer forest. The average denudation rate derived from in-situ ${ }^{10} \mathrm{Be}$ concentrations in soils at the sampling site is $221 \mathrm{t} \mathrm{km}^{-2} \mathrm{yr}^{-1}\left(82 \mathrm{~mm} \mathrm{kyr}^{-1}\right)$ and the CDF of the upper soil horizons averages 0.36 (Dixon and others, 2009). Consequently, chemical weathering rates in the PC sites are roughly $80 \mathrm{t} \mathrm{km}^{-2} \mathrm{yr}^{-1}$ and physical erosion rates are $141 \mathrm{t} \mathrm{km}^{-2} \mathrm{yr}^{-1}$. The regolith profile, 'Balsam-profile', lies about $10 \mathrm{~km}$ to the northwest of the PC sites. This roadcut profile has a depth of about $10 \mathrm{~m}$. Regolith residence time at this site is estimated as 86 kyrs.

\section{Sri Lanka}

The third site is a regolith profile in the central Highlands of Sri Lanka (fig. 2C) located at $1753 \mathrm{~m}$ altitude and exposed along the road from Nuwaraeliya to Welimada. It has been previously presented in Hewawasam and others (2013) and Behrens and others (2015). The site is on a hillslope underlain by charnockite bedrock $\left(\mathrm{SiO}_{2}>65 \%\right.$; plagioclase, $\mathrm{K}$-feldspar and quartz are the dominant minerals, with orthopyroxene and biotite as minor components). The mean annual temperature (MAT) is $16^{\circ} \mathrm{C}$ and the mean annual precipitation (MAP) is $2013 \mathrm{~mm}$. The profile has a depth of $>10 \mathrm{~m}$, with red-yellow lateric soil layer developed in the upper $60 \mathrm{~cm}$ above a reddish and highly weathered saprolite to $6 \mathrm{~m}$. Below this, massive rounded charnockite blocks and corestones occur, indicative of incipient weathering reactions. Vegetation is typical of the region, with a tropical forest hosting at least 97 tree species of which 62 are endemic. The average denudation rate from cosmogenic ${ }^{10} \mathrm{Be}$ from soils close to the sampled regolith profile is $41.5 \mathrm{t} \mathrm{km}^{-2} \mathrm{yr}^{-1}\left(15.4 \mathrm{~mm} \mathrm{kyr}^{-1}\right)$ (Hewawasam and others, 2003). CDF averages 0.5 (Hewawasam and others, 2013), close to the maximum possible for granitic rock. Together, these data imply equivalent rates of physical erosion and chemical weathering: $20.8 \mathrm{t} \mathrm{km}^{-2} \mathrm{yr}^{-1}$. An estimate of regolith residence time at this site is 600 kyrs.

\section{SAMPLING AND METHODS}

\section{Alps}

Samples were taken during a field campaign in July 2010. Six (B1 to B6) soil depth profiles were sampled on a soil-mantled ridge top using a soil corer from the soil surface to $\sim 30 \mathrm{~cm}$, depending on soil thickness. We sampled un-weathered bedrock nearby. Water samples were taken from small rivers draining the catchment area, filtered at $0.2 \mu \mathrm{m}$ into pre-cleaned HDPE bottles and acidified with $\mathrm{HNO}_{3}$. Plant material of the dominant species (mostly grasses and spruce trees) was collected, rinsed with deionized water, oven dried, and stored in plastic bags.

\section{Sierra Nevada}

The samples were collected in May 2010. Several soils were sampled at the PC CZO and a deep saprolite profile ("Balsam-profile") located NE of Shaver Lake (fig. 2B). The soil samples were taken as depth profiles using a soil corer for shallow soil horizons and an auger for deeper soil horizons. One soil depth profile was sampled in catchment P301 from surface down to a depth of $120 \mathrm{~cm}$ (samples SN1 to SN10). Further soil depth profiles were sampled in PC catchments P303 (samples SN21 to SN23) and P304 (samples SN24 to SN26) from the surface down to $30 \mathrm{~cm}$ depth using a soil corer. The individual soil core samples or augered soil samples were afterwards mixed and represent an average of the sampled depth.

At the "Balsam" study site samples were taken down to a depth of $\sim 800 \mathrm{~cm}$ below the surface. The surface of the exposed saprolite was scraped off and samples were taken from the "fresh" saprolite surface with a soil corer where possible. The sampled profile starts at the soil surface, includes the whole soil, the saprolite and extends 
down to the source-rock/saprolite border. We sampled un-weathered bedrock at the bottom of the regolith profile. Water samples have been taken from small streams within the PC CZO and treated as above. Plant material of the dominant vegetation, in particular the pine trees, was sampled from living specimens only and treated as above.

\section{Sri Lanka}

Samples were taken in October 2010 as detailed in Hewawasam and others (2013). The soil and saprolite samples were collected from a vertical section of a regolith profile (samples SL6 to SL29), exposed as a fresh road cut during construction works. Approximately $10 \mathrm{~m}$ upslope from the regolith profile, nine additional soil samples were collected at three parallel sub-sections within the $60 \mathrm{~cm}$ thick soil zone using a soil corer, integrating over depth intervals from 0 to $20 \mathrm{~cm}, 20$ to $40 \mathrm{~cm}$, and 40 to $60 \mathrm{~cm}$. The soil subsections were located about $1.5 \mathrm{~m}$ apart from each other in order to account for potential lateral variability. These soil samples were afterwards combined to produce an average soil sample for each depth interval. Unweathered bedrock samples were taken beneath the regolith profile and water samples were taken from three small, pristine streams located in close vicinity as detailed in Hewawasam and others (2013) and Schuessler and others (2018). Plant material of dominant taxa was collected from living specimens only and treated as above.

\section{Analytical Methods}

Sample preparation.-Rock samples and bulk soil and saprolite samples were crushed in a tungsten carbide mill to $<68 \mu \mathrm{m}$ and digested using $\mathrm{NaOH}$ fusion following Georg and others (2006) and Zambardi and Poitrasson (2011). Soil and saprolite samples were sieved at $2 \mathrm{~mm}$ and subjected to protocols designed to separate $\mathrm{Si}$ in secondary clays and $\mathrm{Si}$ in amorphous silica. The rationale for this approach is that the amorphous phase may be a precursor to 'true' clays (Behrens and others, 2015). We sequentially applied a weak base dissolution protocol developed by Georgiadis and others (2013) for amorphous silica extraction, and a differential settling approach for clay mineral separation. Approximately $500 \mathrm{mg}$ of sample material was added to $10 \mathrm{ml}$ Milli-Q water in a $15 \mathrm{ml}$ polypropylene centrifuge tube and sonicated for 12 hours to disperse the clay size fraction. Afterwards, $0.42 \mathrm{ml}$ of $5 \mathrm{M} \mathrm{NaOH}$ was added to achieve a final molarity of $0.2 \mathrm{M}$. The tubes were placed in an $80^{\circ} \mathrm{C}$ water bath for 5 hours then centrifuged for $25 \mathrm{~min}$ at $4400 \mathrm{rpm}$. The supernatant with the leached amorphous $\mathrm{Si}$ was then passed through a $0.2 \mu \mathrm{m}$ pore size polyethersulfone filter. The clay size fraction was separated from the residuum by the addition of $5 \mathrm{ml}$ Milli- $Q$ water, resuspension, sonication and centrifugation according to Stokes law. This was performed only once, to obtain a fraction dominated by the mineralogical clays, rather than to quantitatively separate the full grain size-fraction. The weakly basic solution containing the amorphous silica extraction and the final supernatant solution containing the clay phase were evaporated in Ag crucibles and combusted for $\geq 1$ hour at $700^{\circ} \mathrm{C}$ in a muffle furnace to remove residual organic matter. Subsequently, $3 \mathrm{ml}$ of 1.6 $\mathrm{M} \mathrm{NaOH}$ was added, evaporated to dryness and used to perform a $\mathrm{NaOH}$ fusion performed above. Vegetation samples were first combusted for 4 hours at $700^{\circ} \mathrm{C}$ in $\mathrm{Ag}$ crucibles, and the remaining ash was digested using the same $\mathrm{NaOH}$ fusion procedure.

For all solutions (that is, those resulting from $\mathrm{NaOH}$ fusion of rock, bulk soil/saprolite, clay, amorphous silica, and plant material, and acidified river water), silicon was separated from the cationic sample matrix using the well-established ionexchange chromatography method of Georg and others (2006). Si blanks of the 
fusion and column separation procedure were in general far below $1 \mu \mathrm{g} \mathrm{Si}$, equivalent to $\ll 1 \%$ of the total Si processed.

Element concentration measurements. - Major and minor element concentrations of the water samples, and of the amorphous and clay fractions post $\mathrm{NaOH}$ fusion solutions, were determined by optical emission spectrometry (ICP-OES, Varian 720 - ES). Samples and standards were measured in a $0.3 \mathrm{M} \mathrm{HNO}_{3}$ matrix with $1000 \mu \mathrm{g} \mathrm{g}^{-1} \mathrm{Cs}$ as a matrix modifier element. To account for the high Na load of the digested samples after alkaline fusion, a known amount of $\mathrm{Na}$ was added to the calibration standard solutions. Precision and accuracy were assessed by repeated measurements of an inhouse artificial standard solution, showing a reproducibility of better than $<5 \%$. Analyses of reference materials over the course of this study indicated an accuracy of better than $8 \%$ for all elements analysed in this study. Bulk sample elemental concentrations were measured by XRF as detailed in von Blanckenburg and others (2021).

Si isotope ratio measurements. - Silicon isotope ratios were measured on a Thermo Neptune multi-collector inductively coupled plasma mass spectrometer (MC-ICP-MS) equipped with an H-skimmer cone and the Thermo Scientific Jet - interface with high or medium resolution slits $(\mathrm{m} / \Delta \mathrm{m}>5000)$. This is sufficient to resolve all critical polyatomic interferences (for example, ${ }^{14} \mathrm{~N}^{16} \mathrm{O}$ on ${ }^{30} \mathrm{Si}$ ). The purified sample solutions were diluted to $0.6 \mu \mathrm{g} \mathrm{g}^{-1}$ to $1.0 \mu \mathrm{g} \mathrm{g}^{-1} \mathrm{Si}$ in a $0.1 \mathrm{M} \mathrm{HCl}$ matrix and introduced into the plasma via a desolvation unit for dry plasma conditions (Apex, ESI) equipped with a $c a .120 \mu \mathrm{min}^{-1}$ self-aspirating nebulizer. Magnesium was added to samples and standards at a matching concentration. Typical sensitivities were $\sim 15 \mathrm{~V} / \mu \mathrm{g} \mathrm{g}^{-1}$ on ${ }^{28} \mathrm{Si}$ (using a $10^{11} \Omega$ resistor). Measurements were conducted on the interference-free low-mass side of the three $\mathrm{Si}$ isotopes. Isotope ratios of samples and standards were measured at least 3 times during a sequence. Instrumental mass bias was corrected using the standard-sample-bracketing approach, assuming a linear trend between the standards before and after the sample. Si and $\mathrm{Mg}$ were monitored dynamically for 30 cycles with an integration time for each cycle of $4 \mathrm{~s}$ for both elements with an idle time of $3 \mathrm{~s}$ after magnet switching. Pure $0.1 \mathrm{M} \mathrm{HCl}$ solutions containing only $\mathrm{Mg}$ were measured before and after each standard-sample-standard block and were used for on-peak zero correction. Typical ${ }^{28} \mathrm{Si}$ intensities from blank solutions were below 10 $\mathrm{mV}$. The measured $\mathrm{Si}$ isotope ratios were corrected using the deviation of measured $\mathrm{Mg}$ isotope ratios from a natural abundance, assuming an exponential mass-bias law, after Cardinal and others (2003) and Oelze and others (2016). These corrected ratios are reported in delta notation relative to the standard reference material NBS28 (NIST RM 8546, quartz sand) as $\delta^{29 / 28} \mathrm{Si}_{\mathrm{NBS} 28}$ and $\delta^{30 / 28} \mathrm{Si}_{\mathrm{NBS} 28}$, expressed in per mil by multiplication of equation (3) with a factor of 1000 :

$$
\delta^{\mathrm{X} / 28} \mathrm{Si}_{\text {NBS28 }}=\frac{\left({ }^{\mathrm{x}} \mathrm{Si} /{ }_{28} \mathrm{Si}\right)_{\text {sample }}}{\left({ }^{\mathrm{x}} \mathrm{Si} /{ }^{28} \mathrm{Si}\right)}-1
$$

Where $\mathrm{X}$ is 29 or 30 . All reported uncertainties on delta values given in the supplementary Data Tables (Frings and others 2021a) are the 95\% confidence interval (CI):

$$
\mathrm{CI}=\overline{\delta^{\mathrm{X} / 28} \mathrm{Si}} \pm t_{n-1} \cdot \mathrm{SE}
$$

where $\overline{\delta^{\mathrm{X} / 28} \mathrm{Si}}$ is the mean of the measured delta values for the sample, $\mathrm{t}_{\mathrm{n}-1}$ is a critical value from Student's t-distribution and $\mathrm{SE}$ is the standard error of the mean. For 
simplicity, we use $\delta^{29} \mathrm{Si}$ and $\delta^{30} \mathrm{Si}$ for $\delta^{29 / 28} \mathrm{Si}_{\mathrm{NBS} 28}$ and $\delta^{30 / 28} \mathrm{Si}_{\mathrm{NBS} 28}$, respectively and take a long-term reproducibility in this lab of $c a .0 .14 \%$ (2s; Oelze and others, 2016) as the uncertainty in all figures and calculations unless the individual sample uncertainty (eq 4) is higher. Several well-characterised reference materials, including BHVO-2, Diatomite and Big-Batch were prepared and measured along with the samples. Their preparation included repeated digestions and chemical purification.

In situ element concentration and silicon isotope ratio analyses.-Mineral specific in situ $\mathrm{Si}$ isotope ratios and element concentrations were measured at all three sites. For Sri Lanka, thin sections from the unweathered centre of a corestone (see Behrens and others, 2015) were analysed simultaneously for their elemental and isotopic composition by femtosecond laser ablation split stream inductively coupled plasma multi collector mass spectrometry (fsLASS-ICP-MCMS; Frick and others, 2016). Samples from the Alps and Sierra Nevada were analysed consecutively for their element composition with the laser-ablation system coupled to a quadrupole ICP-MS (fsLA-ICP-qMS), followed by Si stable isotope analysis (fsLA-ICP-MCMS). For these two sites, the sampling spots are thus not identical.

The fsLA system is a custom-built deep-UV (196 nm) femtosecond laser ablation system (see Schuessler and von Blanckenburg (2014) for technical details). The aerosol is transported in a stream of helium to either a quadrupole ICP-MS (iCAPq, ThermoFisher Scientific), to the Neptune multi-collector ICP-MS, or actively pumped into both instruments for split stream analysis (Frick and others, 2016). The ICP-qMS was tuned daily for highest sensitivity on NIST SRM610, while maintaining a ${ }^{238} \mathrm{U} /{ }^{232} \mathrm{Th}$ ratio close to 1 and $\mathrm{a}{ }^{238} \mathrm{U}^{16} \mathrm{O} /{ }^{238} \mathrm{U}$ ratio below $0.7 \%$. NIST SRM610 was used as external standard, while differences in the ablation yield were corrected using a $100 \mathrm{wt} \%$ oxide normalisation approach (Liu and others, 2008).

Silicon isotope ratios measurements were made as above. Isotope compositions are reported in delta notation as permil deviation relative to either NBS28, or to NIST SRM610 (eq 3), which has a Si isotope composition indistinguishable from NBS28. Raw data processing and background corrections were made following the protocol in Schuessler and von Blanckenburg (2014), including several data rejection/acceptance criteria. To assess the accuracy and precision of laser-ablation concentration and isotope ratio measurements, a range of different international reference materials (BHVO-2G, GOR132G, NIST610 and NIST612) were analysed and compared to literature values (Jochum and others, 2005; Jochum and others, 2011; Schuessler and von Blanckenburg, 2014).

\section{RESULTS}

\section{Si Pools}

Si concentrations for the key Si compartments (bedrock, bulk saprolite, bulk soil, amorphous fraction, clay sized fraction, plants and $\mathrm{Si}$ in dissolved form) are given in table 1 and in Appendix A1. The full dataset is provided in a supporting Data Publication hosted open access at GFZ data services (Frings and others, 2021a) hereafter called "Data Tables". All catchments are underlain by granitoid bedrock with similar elemental Si concentrations of $32.3 \mathrm{wt} \%$ (Alps), $27.7 \mathrm{wt} \%$ (Sierra Nevada) and 31.8 wt \% (Sri Lanka) (see table 1 and von Blanckenburg and others, 2021). There is little variation with depth of bulk Si concentrations within the saprolite or soil of the Alps and the Sierra Nevada sites (fig. A1), which average 32.7 wt \% and 28.9 wt\%, respectively (table 1). Bulk Si concentrations of the Sri Lankan field site decrease to $c a$. 25 wt \% in the uppermost 250 to $50 \mathrm{~cm}$. Si concentrations of the $\mathrm{NaOH}$ leach and clay size fractions are presented relative to the total mass of the sample and so represent the amount of $\mathrm{Si}$ in these phases in the bulk sample. The average concentration of 
TABLE 1

Summary of Si concentrations $( \pm 1 \sigma)$ in bulk bedrock, bulk soils, the amorphous $\mathrm{Si}$ (NaOH leach) and clay-size fractions, and stream water and biomass samples

\begin{tabular}{|c|c|c|c|c|}
\hline Site & Units & Alps & Sierra Nevada & Sri Lanka \\
\hline Bedrock $^{\mathrm{a}}$ & $\overline{\mathrm{wt} \% \mathrm{SiO}_{2}}$ & $68.1 \pm 1.08 \mathrm{n}=6$ & $59.5 \pm 4.34 \mathrm{n}=82$ & $68.1 \pm 0.85 \mathrm{n}=9$ \\
\hline Bulk soil $^{\mathrm{a}}$ & $\mathrm{wt} \% \mathrm{SiO}_{2}$ & $69.9 \pm 0.9 \mathrm{n}=10$ & $61.8 \pm 1.6 \mathrm{n}=20$ & $65.8 \pm 1.6 \mathrm{n}=14$ \\
\hline $\mathrm{NaOH}$ leach & $\mu \mathrm{g} \mathrm{g}^{-1}$ & $1077 \pm 933 n=22$ & $2040 \pm 554 n=28$ & $1370 \pm 340 n=27$ \\
\hline Clay size fraction & $\mu \mathrm{g} \mathrm{g}^{-1}$ & $9210 \pm 6530 n=22$ & $22300 \pm 15100 \mathrm{n}=28$ & $26800 \pm 10700 \mathrm{n}=27$ \\
\hline Stream water dissolved $\mathrm{Si}^{\mathrm{a}}$ & $\mu \mathrm{g} \mathrm{g}^{-1}$ & $1.36 \pm 0.86 \mathrm{n}=5$ & $12.1 \pm 2.57 \mathrm{n}=30$ & $2.11 \pm 0.52 \mathrm{n}=20$ \\
\hline Plant biomass ${ }^{\mathrm{a}}$ & $\mu \mathrm{g} \mathrm{g}^{-1}$ & n.d. & $230 \pm 89.5 \mathrm{n}=9$ & $3260 \pm 2910 n=8$ \\
\hline
\end{tabular}

Concentrations in amorphous $\mathrm{Si}$ and clay size fraction are relative to bulk sample rather than just the separated/ leached fraction.

${ }^{\mathrm{a}}$ Data from (von Blanckenburg and others, 2021).

amorphous $\mathrm{Si}$ (from the $\mathrm{NaOH}$ leach) in bulk regolith is similar at all three field sites, and is in the range of 1000 to $2000 \mu \mathrm{g} \mathrm{g}^{-1}(0.1-0.2 \mathrm{wt} \%)$. There is no clear variation with depth. The $\mathrm{Al} / \mathrm{Si}$ ratio of this $\mathrm{NaOH}$ leach tends to be $>2 \mathrm{~mol} \mathrm{~mol}^{-1}$, suggestive of a non-biogenic origin (Barão and others, 2015), and also does not vary systematically with depth. The concentration of regolith $\mathrm{Si}$ that is hosted in the clay-sized fraction is an order of magnitude higher and is similar for all three sites, at 1 to 2 wt\% (10000 $20000 \mu \mathrm{g} \mathrm{g}^{-1}$ ), though this is a minimum since the separation by settling was performed only once. As with the amorphous fraction, the Si content of the clay sized fraction does not systematically vary with depth. $\mathrm{Al} / \mathrm{Si}$ ratios are lower than the $\mathrm{NaOH}$ leach, equivalent to mean values of $0.55 \mathrm{~mol} \mathrm{~mol}^{-1}$ in the Alps, $0.81 \mathrm{~mol} \mathrm{~mol}^{-1}$ in Sierra Nevada, and $1.02 \mathrm{~mol} \mathrm{~mol}^{-1}$ in Sri Lanka. These are typical of common clay minerals. Although vegetation communities differ between the three field sites (see the online supporting Data Tables and von Blanckenburg and others, 2021), Si concentrations in the leaves, twigs and stem of the dominant species are consistent among the sites, ranging from 0.5 to $5 \mathrm{wt} \%$. Si concentrations in stream waters are lowest in the Alps $\left(\right.$ mean $\left.=1.44 \mu \mathrm{g} \mathrm{g}^{-1}, \mathrm{n}=5\right)$. Mean stream water $\mathrm{Si}$ concentrations for the Sri Lanka site are $3.52 \mu \mathrm{g} \mathrm{g}^{-1}(\mathrm{n}=31)$ and $9.35 \mu \mathrm{g} \mathrm{g}^{-1}(\mathrm{n}=97)$ at the Sierra Nevada site.

\section{Si Isotope Ratios}

A summary of $\delta^{30} \mathrm{Si}$ values for the different compartments is presented in table 2 and figure 3 , and in full in the Data Tables. All sites have bedrock $\delta^{30} \mathrm{Si}$ of around $-0.15 \%$. Compared to this, the amorphous fraction, clay fraction, and plant

TABLE 2

Summary of the Si isotopic ratios ( $\delta^{30} \mathrm{Si}$, in \%o relative to NBS28) of the individual Si pools at the three study sites

\begin{tabular}{lccc}
\hline Site & Alps & Sierra Nevada & Sri Lanka \\
\hline \hline Bedrock & $-0.14 \pm 0.03 \mathrm{n}=9$ & $-0.19 \pm 0.04 \mathrm{n}=6$ & $-0.11 \pm 0.03 \mathrm{n}=5$ \\
Bulk soil and saprolite & $-0.20 \pm 0.05 \mathrm{n}=14$ & $-0.47 \pm 0.18 \mathrm{n}=20$ & $-0.73 \pm 0.27 \mathrm{n}=19$ \\
NaOH leach & $-0.38 \pm 0.47 \mathrm{n}=19$ & $-1.33 \pm 0.64 \mathrm{n}=32$ & $-1.78 \pm 0.25 \mathrm{n}=27$ \\
Clay size fraction & $-0.36 \pm 0.10 \mathrm{n}=19$ & $-1.33 \pm 0.50 \mathrm{n}=32$ & $-2.03 \pm 0.31 \mathrm{n}=27$ \\
Stream water dissolved $\mathbf{S i}^{\mathrm{a}}{ }^{2}$ & $0.88 \pm 0.18 \mathrm{n}=4$ & $1.71 \pm 0.14 \mathrm{n}=19$ & $0.56 \pm 0.15 \mathrm{n}=7$ \\
Plant biomass & $-0.44 \pm 0.21 \mathrm{n}=11$ & $-0.29 \pm 0.31 \mathrm{n}=7$ & $-1.05 \pm 0.31 \mathrm{n}=11$ \\
\hline
\end{tabular}

a) One outlier $\left(\delta^{30} \mathrm{Si}=0.46 \%\right)$ removed from Sierra Nevada dissolved $\mathrm{Si} \delta^{30} \mathrm{Si}$ summary statistics. 


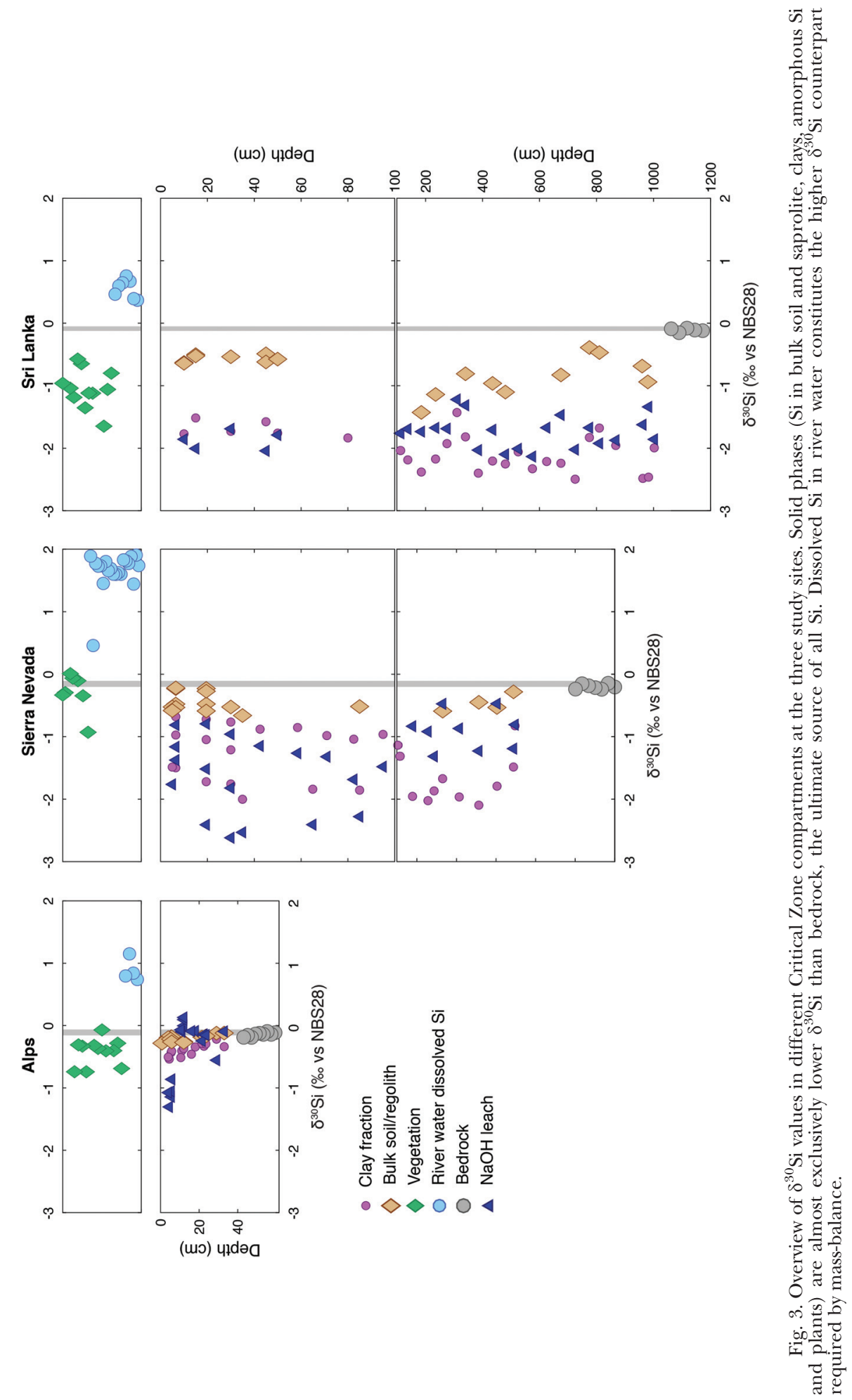


$\delta^{30} \mathrm{Si}$ values are lower. Dissolved $\mathrm{Si}$ in stream waters provides the ${ }^{30} \mathrm{Si}$ enriched counterpart required by mass-balance. The bulk soil and saprolite compositions are intermediate between the lower $\delta^{30} \mathrm{Si}$ clay and amorphous phases, and the higher $\delta^{30} \mathrm{Si}$ bedrock.

Bedrock and mineral-specific $\delta^{30} \mathrm{Si}$. - The $\mathrm{Si}$ isotope composition of the bulk bedrock in the three sampling areas is similar between the three sites: $\delta^{30} \mathrm{Si}=-0.14 \%$ (Alps), $\delta^{30} \mathrm{Si}=-0.19 \%$ (Sierra Nevada) and $\delta^{30} \mathrm{Si}=-0.11 \%$ (Sri Lanka). Mineral specific in-situ determinations yield similar ranges in $\delta^{30} \mathrm{Si}$ at all three sites. Biotite is consistently the lowest $\delta^{30} \mathrm{Si}$ mineral (means $\pm 95 \% \mathrm{CI}$, Alps: $-1.01 \pm 0.38 \%$, Sierra Nevada: $-0.58 \pm 0.04 \%$, Sri Lanka: $-0.47 \pm 0.09 \%$ ). The other major minerals (quartz, plagioclase and K-feldspar) are similar, falling around $-0.2 \%$. Quartz tends to be the highest $\delta^{30} \mathrm{Si}$ mineral (Alps $-0.20 \pm 0.05 \%$, Sierra Nevada: $-0.14 \pm 0.05 \%$, Sri Lanka: $-0.07 \pm 0.08 \%$ o). A summary of the data, together with mineral formulae, is given in table 3 and figure 4.

Bulk soils and saprolites. - The bulk samples of the three sites differ in their $\mathrm{Si}$ isotopic composition. The bulk soil $\delta^{30} \mathrm{Si}$ values of the Swiss Alps site $-0.20 \%$, of the Sierra Nevada site $-0.45 \%$ and of the Sri Lanka site $-0.56 \%$ (fig. 3 and table $2)$. No site exhibits a clear depth dependence in soil $\delta^{30} \mathrm{Si}$. In contrast, bulk saprolite samples vary systematically with depth in Sierra Nevada and Sri Lanka. Note there is only very thin saprolite (C-horizons) at the Swiss Alps sampling site. Mean saprolite $\delta^{30} \mathrm{Si}$ in Sierra Nevada is $-0.52 \%$ and in Sri Lanka is $-0.86 \%$. The general trend for the saprolite is an evolution to lower $\delta^{30} \mathrm{Si}$ with decreasing depth. At both field sites soil $\delta^{30} \mathrm{Si}$ is higher than the uppermost saprolite samples.

Amorphous and clay-size fraction $\delta^{30} \mathrm{Si}$. - The amorphous and clay fractions of the three sites show no obvious depth dependence. A general observation is that the mean $\delta^{30} \mathrm{Si}$ of the amorphous and clay fraction are highest in the Alps, lowest in Sri Lanka and intermediate in Sierra Nevada. There is a tendency that at depth (the Alps) or within the saprolite (Sierra Nevada and Sri Lanka) the amorphous fraction is higher in $\delta^{30} \mathrm{Si}$ than the corresponding clay fraction. This tendency reverses in the upper part of the profile (Alps) or within the soil (Sierra Nevada and Sri Lanka; fig. 3). To best isolate a secondary-phase signature, we apply a correction for the potential contamination of the clay size-fraction by primary, rockforming silicates (considering plagioclase, feldspars, biotite and quartz as potential contaminating phases; see Appendix B for details, results are given in table 4). This correction is based on the mineral formulae and $\delta^{30} \mathrm{Si}$ values presented in table 3. The correction is small: our best estimate of the proportion of Si from primary phases in the clay separates is $33 \%$ in the Alps, $13 \%$ in Sierra Nevada, and $0.2 \%$ in Sri Lanka. This equates to corrections of $+0.07,-0.20 \%$, and less than $-0.01 \%$, respectively. XRD spectra from clay-size separates of the Sri Lanka profile (Behrens and others, 2015) corroborate the lack of primary minerals in the claysize fraction. We thus believe we have obtained $\delta^{30} \mathrm{Si}$ values for the secondary clay component, rather than a mixture of mineralogical clays and clay-sized primary minerals.

Vegetation and dissolved Si $\delta^{30} \mathrm{Si}$. - The $\delta^{30} \mathrm{Si}$ values of the individual plant parts vary between $-0.74 \%$ and $-0.07 \%$ (mean $=-0.42 \%$ ) for the Alps site, between $-0.93 \%$ and $+0.01 \%$ (mean $=-0.29 \%$ ) for the Sierra Nevada site and between $-1.65 \%$ and $-0.57 \%$ (mean $=-1.05 \%$ ) for the Sri Lankan site. The Si isotope ratios of stream water samples are higher than bedrock at all three sites. Dissolved $\mathrm{Si}$ $\delta^{30} \mathrm{Si}$ values for the Alps range between 0.74 to $1.15 \%$ (mean $=0.88 \%$ ). For the Sierra Nevada streams, they range between 0.46 to $1.91 \%$ o $($ mean $=1.65 \%$ ), and for the Sri Lanka sampling site, between 0.37 to $0.76 \%$ ( mean $=0.56 \%$ o . 


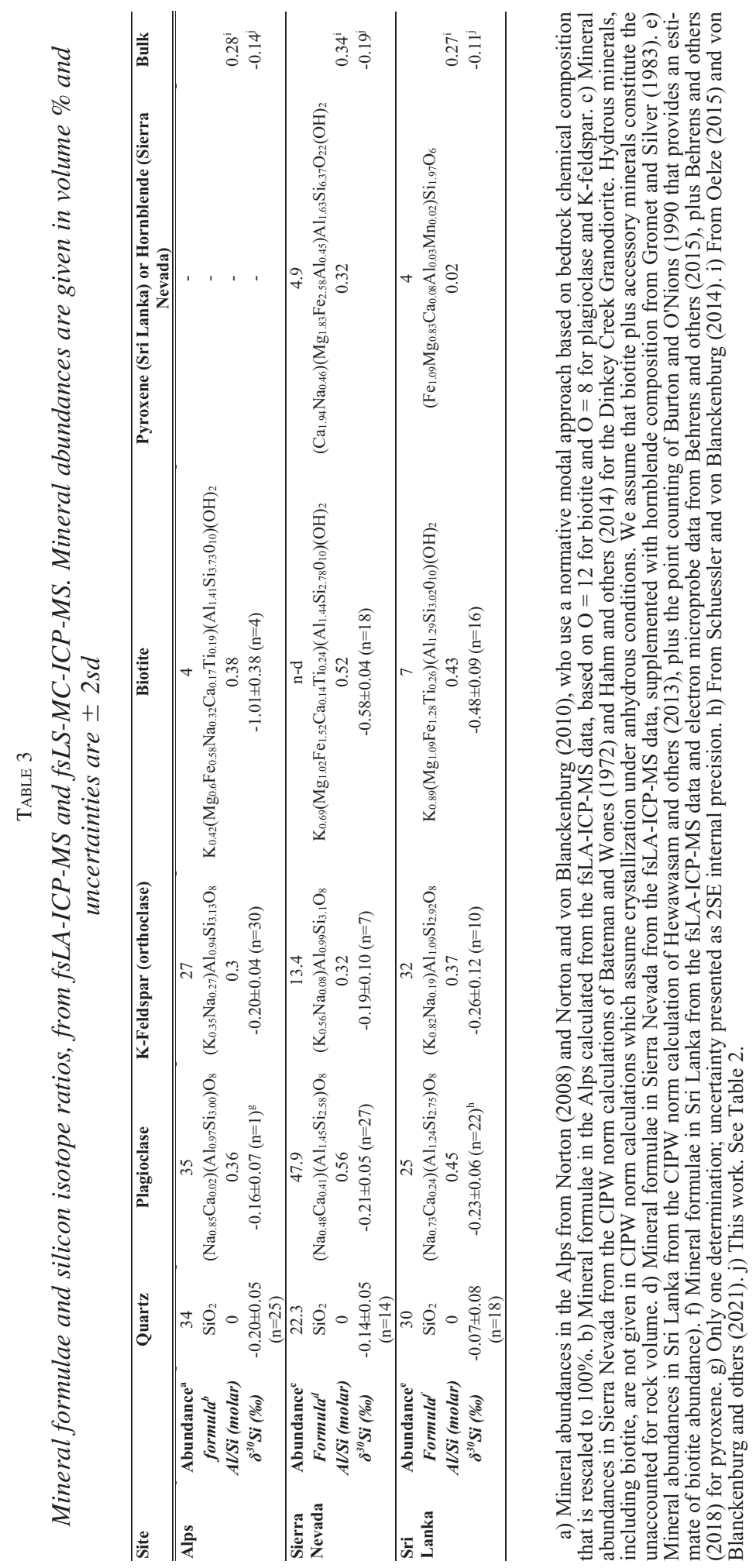




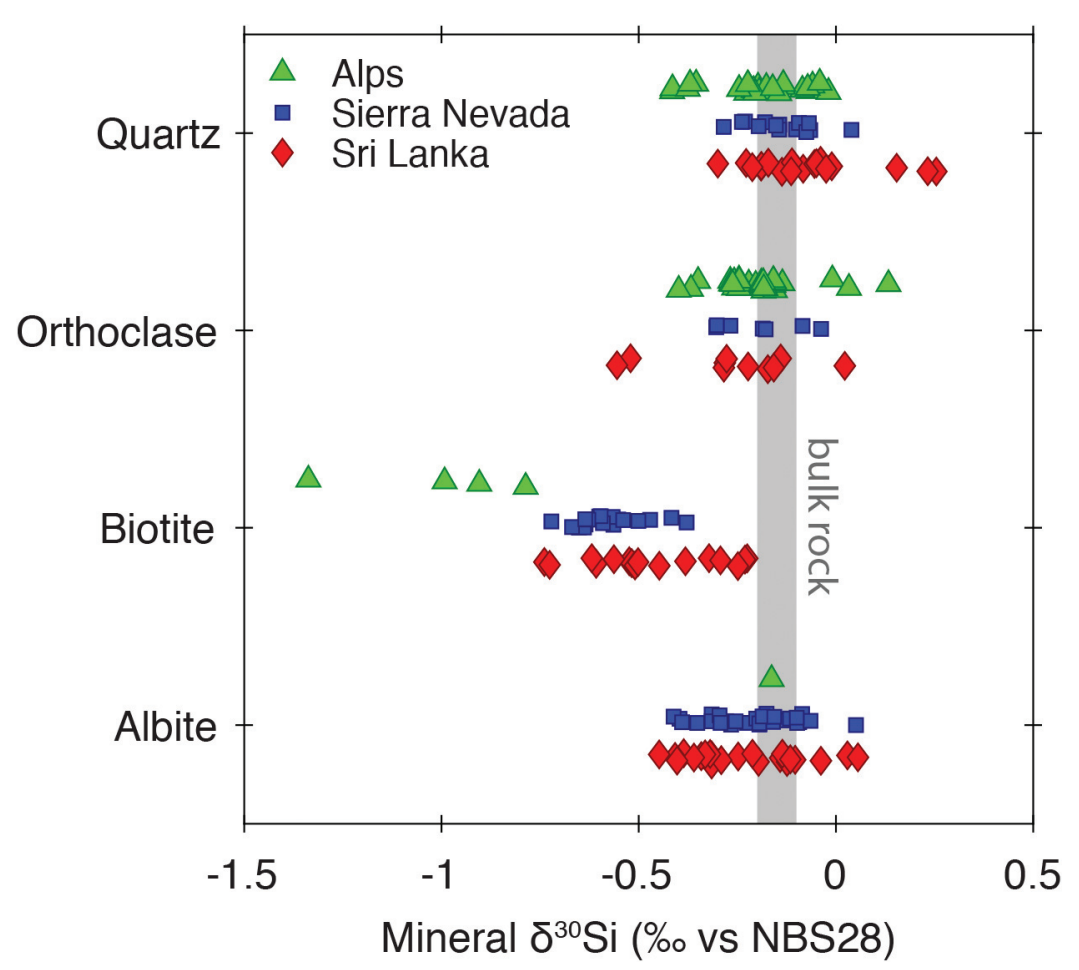

Fig. 4. Primary mineral in situ $\delta^{30} \mathrm{Si}$ values determined by femtosecond Laser Ablation-MC-ICP-MS. In line with previous work, biotite is consistently the most ${ }^{30} \mathrm{Si}$ depleted mineral. Because $\delta^{30} \mathrm{Si}$ values differ between minerals, and so does their susceptibility to weathering, the silicon being released into solution (parameter \#1 in fig. 1) depends on the minerals that actually dissolve. Full results are given in table 3. Gray shaded area indicates the range of bulk-rock $\delta^{30} \mathrm{Si}$ at the three sites.

\section{DISCUSSION}

Figure 1 shows how simple mass-balances for $\mathrm{Si}$ isotope partitioning in the weathering zone (for example, Bouchez and others, 2013; Baronas and others, 2018) condense to three key parameters: the $\delta^{30} \mathrm{Si}$ of $\mathrm{Si}$ released from dissolution of primary minerals (\#1, red arrow), the partitioning of Si between solute and secondary phases

\section{TABLE 4}

Correction of clay-size fraction $\delta^{30}$ Si for possible contamination from primary minerals, termed 'inherited' Si in the clay-size fraction, with details given in Appendix B

\begin{tabular}{|c|c|c|c|c|c|c|}
\hline Site & $\begin{array}{c}\text { Measured } \\
\text { clay } \delta^{30} \mathrm{Si} \\
(\% 0) \\
\end{array}$ & $\begin{array}{c}\text { Measured } \\
\mathrm{Al} / \mathrm{Si} \\
(\mathrm{mol} / \mathrm{mol}) \\
\end{array}$ & $\begin{array}{c}{[\mathrm{Si}]_{\text {clay }}} \\
\left(\mu \mathrm{g} \mathrm{g}^{-1}\right)^{\mathrm{a}}\end{array}$ & $\begin{array}{c}\text { Mean } \\
\text { inherited } \mathrm{Si} \\
(\%) \\
\end{array}$ & $\begin{array}{c}\text { Mean } \\
\text { Corrected Clay } \\
\delta^{30} \mathrm{Si} \\
\end{array}$ & Difference \\
\hline Alps & $-0.36 \pm 0.09$ & $0.56 \pm 0.08$ & 9210 & $33.0 \pm 14.5$ & $-0.29 \pm 0.16$ & $0.07 \pm 0.08$ \\
\hline $\begin{array}{l}\text { Sierra } \\
\text { Nevada }\end{array}$ & $-1.26 \pm 0.49$ & $0.85 \pm 0.12$ & 22350 & $17.3 \pm 19.1$ & $-1.53 \pm 0.44$ & $0.20 \pm 0.26$ \\
\hline $\begin{array}{l}\text { Sri } \\
\text { Lanka }\end{array}$ & $-2.03 \pm 0.31$ & $1.02 \pm 0.28$ & 26830 & $0.2 \pm 0.8$ & $-2.03 \pm 0.31$ & $0.00 \pm 0.01$ \\
\hline
\end{tabular}

The difference in $\delta^{30} \mathrm{Si}$ values is overall small, lending support to the success of the clay separation protocol. a) Concentrations refer to bulk sample, not the amorphous or clay-size fraction specifically; see main text for details. 
(\#2, blue arrow) and the fractionation factors associated with that partitioning (\#3, green arrow). In the following, we show that all of these factors vary systematically along the erodosequence.

\section{Parameter \#1: $\delta^{30} S i_{\text {initial }}$ - Incongruent Weathering at the Rock-Scale?}

The granitic bedrock at all three sites has similar bulk rock $\delta^{30} \mathrm{Si}$ of $c a .-0.15 \%$ (fig. 3; table 2). Since primary mineral dissolution kinetics are mineral-specific (Churchman and Lowe, 2012), and our in situ data has shown that Si isotope ratios in bedrock can differ between minerals (see also Méheut and Schauble, 2014; Savage and others, 2014), some of the inter-site variability in clay, plant and water $\delta^{30} \mathrm{Si}$ may be due to differing contributions of the primary minerals to total weathering. This rarely receives attention in metal stable isotope geochemistry, though the effect is well known for radiogenic isotope ratios (for example, Harlavan and others, 1998). Table 3 details the chemical and $\mathrm{Si}$ isotope composition of the main rock-forming minerals at our three sites. The three sites display large ranges of mineral $\delta^{30} \mathrm{Si}$ values, with a maximum range of $0.85 \%$ in the Alps. It is therefore plausible that inter-site differences in the relative contributions of each mineral induce differences in $\delta^{30} \mathrm{Si}_{\text {initial }}$.

Plagioclase $\delta^{30} \mathrm{Si}$ at our three sites averages $c a .-0.20 \%$, in line with previously published Sri Lanka values of $-0.22 \pm 0.19 \%$ (Schuessler and von Blanckenburg, 2014). Values between $-0.49 \%$ to $-0.10 \%$ have been determined elsewhere (Ziegler and others, 2005b; Savage and others, 2011; Savage and others, 2012; Steinhoefel and others, 2017). Our low $\delta^{30} \mathrm{Si}$ biotite values from fsLA-MC-ICP-MS (individual determinations from -1.34 to $-0.22 \%$ ) are also consistent with previous work. For example, laser ablation MC-ICP-MS analyses produced values of $c a$. $-0.70 \%$ for biotite grains in the granite of the German black forest (Steinhoefel and others, 2011; Steinhoefel and others, 2017). Elsewhere, biotite separates from a Puerto Rican granite yielded a value of $-0.60 \%$ (Ziegler and others, 2005b). Such low values relative to the bulk UCC value of $-0.25 \pm 0.16 \%$ o (Savage and others, 2013), or a granite value of $-0.23 \pm 0.15 \%$ o (Savage and others, 2012) are also consistent with mineral separates in granites (Savage and others, 2014). Here, the authors report that biotite was $\sim 0.28 \%$ lighter than the bulk rock. They are also in line with the $a b$ initio calculations of Méheut and others (2009) and Méheut and Schauble (2014), which predict that the more polymerized, cation-rich minerals should be more fractionated towards lighter (lower $\delta^{30} \mathrm{Si}$ ) values.

The difference in $\delta^{30} \mathrm{Si}$ between many of the major minerals in the granites underling the three sites (quartz, K-Feldspar, Plagioclase) is not large (table 3 ). The important result of our in situ $\delta^{30} \mathrm{Si}$ determinations is not the absolute values, but rather the demonstration that minerals can and do differ in their $\delta^{30} \mathrm{Si}$. It is noteworthy that the inter-site difference in mineral $\delta^{30} \mathrm{Si}$ is also non-negligible. For example, we observe an inter-site range in biotite of $c a$. $0.53 \%$, and in quartz of $0.13 \%$. Published plagioclase data also span a range of $c a .0 .3 \%$ (see above). Overall, the inter-mineral $\delta^{30} \mathrm{Si}$ variations that we observe are large, resolvable and consistent with previous empirical and theoretical work.

To investigate the potential impact of differential mineral weathering on bulk soil and clay fraction Si isotope ratios, we invert bulk soil and saprolite chemical compositions to quantitatively estimate the relative contribution of each mineral to the bulk sample. Details of the approach are given in Appendix C while figure 5 shows the results. The most intensely weathered site, the Sri Lanka highlands, has no primary mineral phases left in the upper regolith and soil besides quartz, with a $\delta^{30} \mathrm{Si}$ value of $-0.07 \pm 0.08 \%$ (table 3 ). Plagioclase, biotite and pyroxene all display sharp gradients in abundance at the saprolite/bedrock boundary. K-feldspar is the only mineral that persists a few metres into the regolith, in line with the known mineralogy 

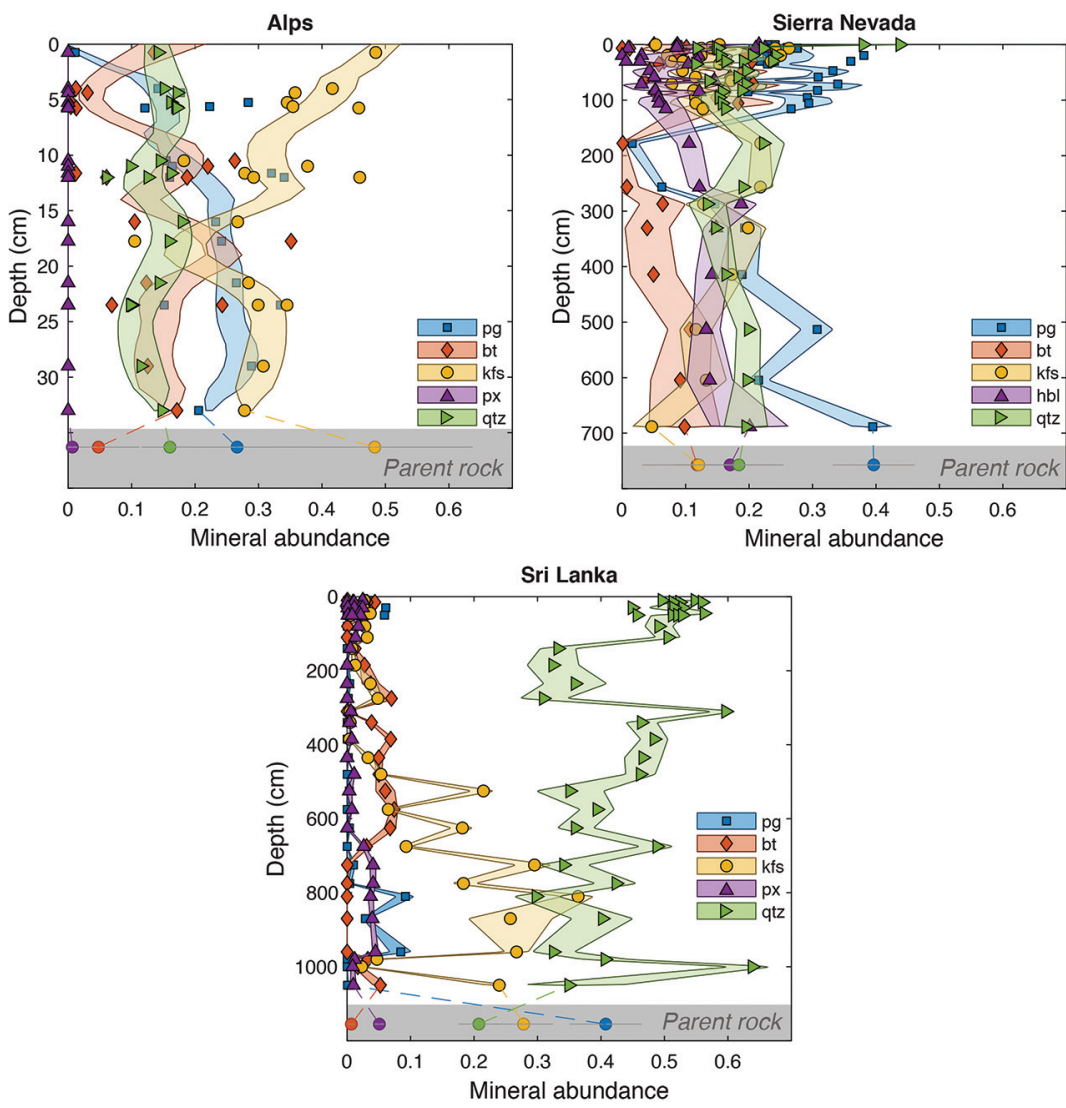

Fig. 5. Modelled mineralogy for the three study sites derived by minimising the RMSE of a series of mass-balance equations for the major elements $\mathrm{Si}, \mathrm{Al}, \mathrm{Ca}, \mathrm{Na}, \mathrm{K}, \mathrm{Mg}$ and $\mathrm{Fe}$ (see supplementary text for details). Mineral stoichiometries as determined by fsLA-ICP-qMS (table 3) or $\mathrm{NaOH}$ fusion for the clay fraction are used as input (table 5). Legend abbreviations are $p g$ plagioclase; $b t$ biotite; $k f s \mathrm{~K} \_$feldspar; $p x$ pyroxene; $h b l$ hornblende: qtz quartz. The results confirm that all primary minerals except quartz are depleted in the supply limited Sri Lanka site, but that primary minerals persist to be eroded in the kinetically limited Sierra Nevada and Alps sites.

(Behrens and others, 2015). In the Alps, conversely, the model suggests there is little depletion of the primary rock-forming minerals and little in-situ clay formation. The Sierra Nevada site represents an intermediate setting, where the model predicts most primary minerals persist until the surface, albeit depleted relative to bedrock. Secondary clay minerals do form, in line with nearby mineralogical investigations. Kaolinite was the only secondary clay detected by XRD analyses of bulk samples (Uhlig and others, 2017). Elsewhere, XRD of clay size separates from a nearby site in Sierra Nevada revealed the presence of hydroxyl-Al interlayered vermiculite and gibbsite (Dahlgren and others, 1997).

The $\delta^{30} \mathrm{Si}$ of solubilized silicon will reflect the weighted mean of all primary phases lost between rock and topsoil, as derived from the geochemical inversion (fig. 5). For Sri Lanka, only quartz persists to the surface. The dissolving minerals are thus only slightly lower than bulk rock (table 2 ). At the Sierra Nevada Balsam profile (samples below $100 \mathrm{~cm}$ in fig. 5), biotite and plagioclase are indicated to become depleted towards the top while the other minerals are not (fig. 5). These minerals yield a weighted mean $\delta^{30} \mathrm{Si}$ of $-0.28 \%$. In the Alps, no consistent mineral depletion trends 
emerge, reflecting the kinetically limited weathering regime. If the interpretation of biotite weathering being the dominant mineral alteration reaction is correct, $\delta^{30} \mathrm{Si}_{\text {intial }}$ could be as low as $-1 \%$. Including some plagioclase weathering would shift this value towards the bulk rock composition. Overall, bulk rock measurements of $\delta^{30} \mathrm{Si}$ are thus a reasonable approximation for solubilised $\mathrm{Si}\left(\delta^{30} \mathrm{Si}_{\text {initial }}\right.$, \#1 in fig. 1) at long-residence time, supply-limited weathering regime sites (for example, Sri Lanka). Importantly, bulk rock $\delta^{30} \mathrm{Si}$ values are not necessarily representative of solubilised $\mathrm{Si}$ for short residence time, kinetically limited sites (for example, the Alps here). We speculate the maximum range of $\delta^{30} \mathrm{Si}_{\text {initial }}$ observed in granitoid settings is likely of the order $\sim 0.2 \%$. Future work could seek to characterise primary mineral $\delta^{30} \mathrm{Si}$ and directly estimate mineral abundance profiles, for example, via a quantitative XRD approach.

Fractionation during dissolution? - A potential confounding factor relates to whether mineral dissolution is associated with isotope fractionation. Experiments with amorphous $\mathrm{SiO}_{2}$ phases have been inconsistent. Both preferential release of the lighter isotopes (Demarest and others, 2009; Sun and others, 2014) or no fractionation (Wetzel and others, 2014) have been reported. Ziegler and others (2005a) observed the preferential release of the lighter ${ }^{28} \mathrm{Si}$ during early basalt dissolution, but that the ${ }^{30} \mathrm{Si} /{ }^{28} \mathrm{Si}$ ratio of solubilised $\mathrm{Si}$ eventually returned to that of the parent material. Similar patterns have been observed for $\mathrm{Mg}, \mathrm{Zn}$ and $\mathrm{Fe}$ isotopes (Brantley and others, 2004; Kiczka and others, 2010; Wimpenny and others, 2010; Weiss and others, 2014; Pokharel and others, 2019). In general, the interpretation for this phenomenon is kinetically controlled release of the lighter isotopes from mineral surfaces during early dissolution, creating a residual, isotopically heavier, surface layer. For dissolution to proceed further into the mineral, this layer must first be removed - so the net effect is congruent weathering (Druhan and others, 2015). These transient effects are seen experimentally on timescales of days to weeks, so rock residence time in the weathering zone should be similar for this apparent fractionation to be visible - we suggest fractionation during dissolution is likely not important here. One exception may be found in weathering reactions that do not necessarily follow a dissolution-reprecipitation pathway, but rather a solid transformation with some Si loss. A speculative example might be the biotite-smectite transformation in the Alps, and may be part of the explanation for why the claysize fraction of the Alps samples are similar or higher $\delta^{30} \mathrm{Si}$ than the primary biotite grains.

Parameter \#2: $f_{S i}$ - Weathering Reaction Stoichiometries Define Si Mass-Balance

The second key control on the absolute value of isotope ratios in the weathering zone is the degree to which fractionation factors can be expressed - the fraction of educt converted to product (\#2 in fig. 1). At complete conversion of phase A to $\mathrm{B}$, there can be no expression of any fractionation - no matter its magnitude. One constraint that is, often not considered in metal stable isotope geochemistry is that mineral weathering reactions have stoichiometries that define the degree of conversion. Table 5 lists the dominant weathering reactions occurring at the three sites. The proportion of Si mobilized during dissolution of a primary mineral that is retained in a secondary mineral, $f_{s e c}^{S i}$ (\#2 in fig. 1), can be calculated making the assumption that aluminium is immobile during mineral transformation reactions:

$$
f_{\text {sec }}^{S i}={ }^{(\mathrm{Al} / \mathrm{Si})_{\text {parent }}} / /_{(\mathrm{Al} / \mathrm{Si})_{\text {sec }}}
$$


TABLE 5

Summary and stoichiometries of the key weathering reactions occurring along the AlpsSierra Nevada-Sri Lanka erodosequence. Clay mineral formulae are based on the primarymineral correction as detailed in Appendix B

\begin{tabular}{lccc}
\hline Site & Alps & Sierra Nevada & Sri Lanka \\
\hline $\begin{array}{l}\text { Characteristic } \\
\text { reaction }\end{array}$ & Biotite to smectite & Feldspar to kaolinite & Plagioclase to kaolinite \\
\hline \hline $\begin{array}{l}\text { Reference } \\
\text { Reactant }\end{array}$ & 1 & 2,3 & 4 \\
Ideal product $^{\mathbf{b}}$ & $\mathrm{K}_{0.65}\left(\mathrm{Mg}_{1.10}, \mathrm{Fe}_{0.93)}\left(\mathrm{Al}_{1.25} \mathrm{Si}_{2.30} \mathrm{O}_{10}\right)(\mathrm{OH})_{2}\right.$ & $\left(\mathrm{K}_{0.56} \mathrm{Na}_{0.08}\right) \mathrm{Al}_{0.99} \mathrm{Si}_{3.1} \mathrm{O}_{8}$ & $\left(\mathrm{Na}_{0.74} \mathrm{Ca}_{0.25} \mathrm{~K}_{0.02}\right) \mathrm{Al}_{1.25} \mathrm{Si}_{2.75} \mathrm{O}_{8}$ \\
Actual product $^{\mathbf{c}}$ & $(\mathrm{Na}, \mathrm{Ca})_{0.33}\left(\mathrm{Al}, \mathrm{Mg}_{2}\left(\mathrm{Si}_{4} \mathrm{O}_{10}\right)(\mathrm{OH})_{2}\right.$ & $\mathrm{Al}_{2} \mathrm{Si}_{2} \mathrm{O}_{5}(\mathrm{OH})_{4}$ & $\mathrm{Al}_{2} \mathrm{Si}_{2} \mathrm{O}_{5}\left(\mathrm{OH}_{4}\right.$ \\
$\begin{array}{l}\text { Reactant Al} / \mathbf{S i} \\
\text { Actual Product }\end{array}$ & $\mathrm{Ca}_{0.09}\left(\mathrm{Al}_{1.04} \mathrm{Mg}_{0.64}\right)_{2}\left(\mathrm{Si}_{3.05} \mathrm{O}_{10}\right)(\mathrm{OH})_{2}$ & $\mathrm{Al}_{1.43} \mathrm{Si}_{1.56} \mathrm{Mg}_{0.3} \mathrm{Ti}_{0.06} \mathrm{O}_{5}(\mathrm{OH})_{4}$ & $\mathrm{Al}_{1.59} \mathrm{Si}_{1.67} \mathrm{Mg}_{0.05} \mathrm{Ti}_{0.03} \mathrm{O}_{5}(\mathrm{OH})_{4}$ \\
$\mathbf{A l} / \mathbf{S i}$ & 0.54 & 0.32 & 0.45 \\
$\mathbf{f S i}^{\mathbf{d}}$ & 0.68 & 0.92 & 0.95 \\
\hline
\end{tabular}

The reactant and product do not necessarily combine in balanced formulae since they represent only the domi-

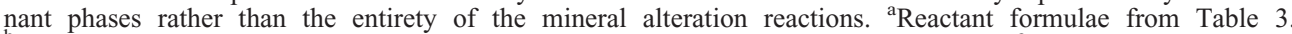
${ }^{b}$ Montmorillionite shown for illustrative purposes in the Alps; kaolinite shown elsewhere. ${ }^{\mathrm{c}}$ Stochiometry calculated assuming oxygen-numbers as in the ideal formulae (12 for smectite-group minerals, 9 for kaolinite). Minerals are not necessarily charge-balanced since trace constituents and Fe are not shown. ${ }^{\mathrm{d}}$ From Eqn. 5. References: 1: Egli, Mirabella, and Fitze (2001); 2: Aguirre (2019); 3: Dahlgren and others (1997); 4: Behrens and others (2015).

This yields values from 0.35 to 0.80 (table 5 ), decreasing from lower weathering intensity (the Alps) to more intense, kaolinite forming sites (Sierra Nevada and Sri Lanka). This means that even when initial $\delta^{30} \mathrm{Si}$ is uniform, and secondary clays form with a constant fractionation factor, the clay $\delta^{30} \mathrm{Si}$ would differ by $>50 \%$ because of the different fractions of Si transferred from fluid to clay. While this is an oversimplification, it demonstrates that clay $\delta^{30} \mathrm{Si}$ is often largely set by the reaction stoichiometry. The predictions are in agreement with the observation (Opfergelt and others, 2012) that smectite group clays are closer in $\delta^{30} \mathrm{Si}$ to their parent material than kaolinite: a larger fraction of the parent $\mathrm{Si}$ is transferred into the clay. Steinhoefel and others (2017) had also previously noted that in situations where the clay minerals are formed by physical transformations of primary phyllosilicates with negligible Si loss, they inherit the $\delta^{30} \mathrm{Si}$ of the parent phase. In the Amazon basin, Hughes and others (2013) infer the mineralogy of secondary clays being formed from river geochemistry, and show that that this relates to isotope partitioning. The implication is that the mineralogy of the secondary phases governs the mass-balance control over how a $\mathrm{Si}$ isotope fractionation factor can be expressed (\#2 in fig. 1). Because clay mineralogy in turn is set by weathering intensity (Biscaye, 1965; Thiry, 2000; Frings, 2019), both fluid and clay $\delta^{30} \mathrm{Si}$ are affected by weathering intensity, even if fractionation factors are uniform. As we show below, clay mineralogy also affects the clay fractionation factor itself, however (\#3 in fig. 1). Note that in our companion paper (Frings and others, 2021b) we discuss the importance of $f_{\text {org }}^{S i}$ - the net partitioning (and presumably export) of $\mathrm{Si}$ into biomass.

Parameter \#3: $\varepsilon_{\text {upt }}$ and $\varepsilon_{\text {prec }}$ - Silicon Isotope Fractionation Factors Vary along the Erodosequence

We use the isotope difference $\Delta^{30} \mathrm{Si}$ between the $\delta^{30} \mathrm{Si}$ of dissolved $\mathrm{Si}$ and secondary clay or vegetation $\mathrm{Si}$ (that is, $\delta^{30} \mathrm{Si}_{\text {diss }}-\delta^{30} \mathrm{Si}_{\text {clay }}$, or $\delta^{30} \mathrm{Si}_{\text {diss }}-\delta^{30} \mathrm{Si}_{\text {veg }}$ ) as an approximation for the Si fractionation $\varepsilon_{\text {prec }}$ and $\varepsilon_{\text {upt }}$ associated with clay precipitation or plant uptake, respectively (eq 1, \#3 in fig. 1, see Appendix D and eq S7). This is equivalent to the $\Delta_{\text {prec }}$ and $\Delta_{\text {upt }}$ notation of Bouchez and others (2013) and is a good 
approximation for small fractionations and if fluxes in the weathering zone are at steady-state (see Appendix D). Because this approach uses isotope differences it is not susceptible to bias introduced by the choice of parent $\delta^{30} \mathrm{Si}$, which we show above may be variable. To derive these values, we average all measured water samples, clay samples and plant samples at each site and use these values to calculate Si isotope fractionations associated with clay precipitation or plant uptake. Note that the fractionation cannot simply be taken as the isotope difference between bedrock and secondary clay, without accounting for mass-balance constraints (see Discussion; \#2 in fig. 1). Importantly, the isotope difference $\Delta^{30} \mathrm{Si}$ only approximates fractionations for two related, exchanging phases (see Appendix D). The approach used here implicitly assumes that the river dissolved $\mathrm{Si}$, and regolith clays, are representative of material leaving the catchment. It thus yields estimates of apparent fractionation, integrated over the entire system that combine the net result of multiple fractionating steps. It also implicitly assumes that stream $\mathrm{dSi} \delta^{30} \mathrm{Si}$ is not altered by in-situ diatom production. As discussed in Frings and others (2021b), and demonstrated in for example Cary and others (2005), this is likely the case for these small headwater streams. A summary and comparison to literature values is given table 6 for $\varepsilon_{u p t}$ and table 7 for $\varepsilon_{\text {prec }}$.

Si isotope fractionation by vegetation. - $\mathrm{Si}$ is taken up by plants in the form of silicic acid $\left(\mathrm{Si}(\mathrm{OH})_{4}\right)$, either through specialised transporter channels or passively across the membrane (Ma and Yamaji, 2008). Plant Si uptake is generally associated with a discrimination against ${ }^{30} \mathrm{Si}$ from the substrate the plants grow in. Several studies have reported plant $\mathrm{Si}$ isotope fractionations $\varepsilon_{u p t}$, that we summarise in table 6 . Once the silicon is taken up, further fractionation occurs during translocation, such that ${ }^{28} \mathrm{Si}$ becomes progressively depleted from the roots to the leaves (for example, Ding and others, 2005; Hodson and others, 2008; Frick and others, 2020). In line with these studies we observe the preferential uptake of ${ }^{28} \mathrm{Si}$ : biomass $\delta^{30} \mathrm{Si}$ values are mostly lower than stream water values and underlying bedrock values (fig. 3 and table 2). As described above, erodosequence plant $\mathrm{Si}$ isotope fractionations are approximated as the isotope difference between river water $\delta^{30} \mathrm{Si}$ and sampled plant biomass $\delta^{30} \mathrm{Si}$ and equate to $-1.30 \%,-1.94 \%$, and $-1.60 \%$ for the Alps, Sierra Nevada, and Sri Lanka, respectively (table 6). These are larger than experimentally derived plant isotope fractionation factors. However, our sampling strategy does not easily permit a bulk plant $\delta^{30} \mathrm{Si}$ value to be estimated - we did not sample root biomass, for example. The plant $\delta^{30} \mathrm{Si}$ data thus convolve $\mathrm{Si}$ isotope fractionation during Si uptake with $\mathrm{Si}$ isotope fractionation during translocation within the plant itself.

Si isotope fractionation associated with clay formation. - In line with the vast majority of clay mineral $\delta^{30} \mathrm{Si}$ determinations to date, our clay samples are ${ }^{30} \mathrm{Si}$ depleted relative to bedrock (Ziegler and others, 2005b; Cornelis and others, 2010; Opfergelt and others, 2010; Opfergelt and others, 2012; Cornelis and others, 2014). This general trend is independent of underlying lithology (for example, Ziegler and others, 2005a vs. Ziegler and others, 2005b) or climate (for example, Cornelis and others, 2014 vs. Frings and others, 2014) and is also reflected in isotopically heavy river dissolved $\mathrm{Si}$ (for example, Hughes and others, 2012; Hughes and others, 2013). Interestingly, the depletion in secondary phase ${ }^{30} \mathrm{Si}$ relative to the parent contrasts with increasingly sophisticated ab initio calculations (Dupuis and others, 2015; Fujii and others, 2015; He and others, 2016) and experimental work (Oelze and others, 2014; Roerdink and others, 2015; Stamm and others, 2019). These studies demonstrate that at isotopic equilibrium, the solid phase either has no resolvable discrimination or preferentially incorporates the heavier ${ }^{30} \mathrm{Si}$ isotope, with ${ }^{28} \mathrm{Si}$ correspondingly enriched in the dissolved phase. River dissolved $\mathrm{Si}$ is essentially never lower in $\delta^{30} \mathrm{Si}$ than bedrock, which is thus a clear indication that isotopic equilibrium between clay and solute is not 


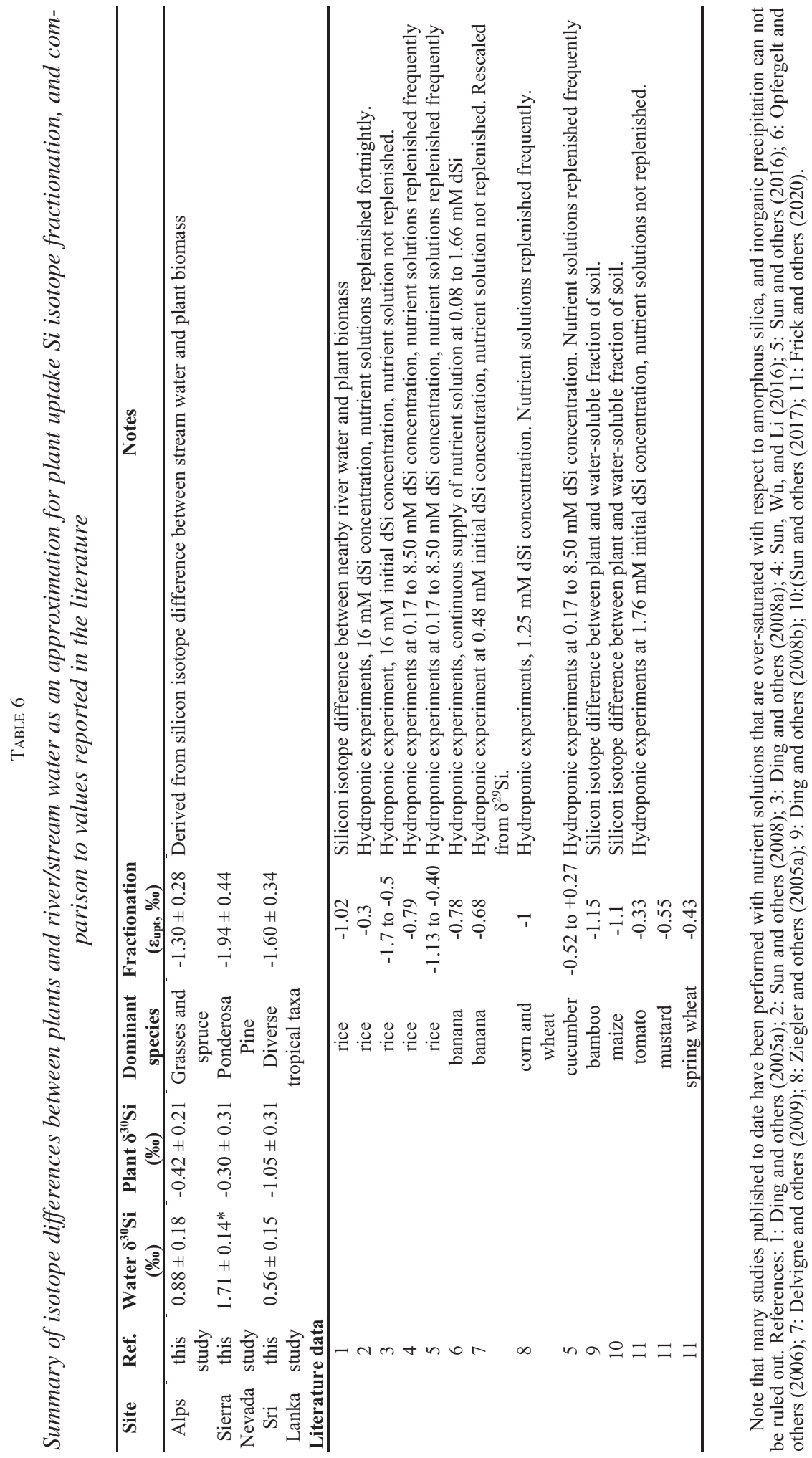


TABLE 7

Summary of Si isotope differences between clay size fraction $\delta^{30}$ Si and river/stream water $\delta^{30} \mathrm{Si}$ as an approximation for the magnitude of Si isotope fractionation ( $\varepsilon_{\text {clay }} ;$ Eqn. 5)

\begin{tabular}{|c|c|c|c|c|c|c|}
\hline Site & Reference & Lithology & $\begin{array}{c}\text { Water } \delta^{30} \mathrm{Si} \\
(\% \text { ) }\end{array}$ & $\begin{array}{c}\text { Clay } \delta^{30} \mathrm{Si} \\
(\% \circ)\end{array}$ & $\begin{array}{c}\text { Dominant secondary } \\
\text { mineralogy }\end{array}$ & $\begin{array}{c}\text { Fractionation } \\
\left(\varepsilon_{\text {prec }}, \%\right)\end{array}$ \\
\hline Alps & This study & Granite & $0.88 \pm 0.18$ & $-0.24 \pm 0.09$ & "Smectite/vermiculite ${ }^{\mathrm{a}}$ & $-1.12 \pm 0.20$ \\
\hline Sierra Nevada & This study & Granite & $1.71 \pm 0.14^{*}$ & $-1.65 \pm 0.49$ & Kaolinite ${ }^{\mathrm{b}}$ & $-3.36 \pm 0.51$ \\
\hline Sri Lanka & This study & Granite & $0.56 \pm 0.15$ & $-2.14 \pm 0.30$ & Kaolinite $^{\mathrm{c}}$ & $-2.70 \pm 0.34$ \\
\hline \multicolumn{7}{|c|}{ Literature data (not inherited phyllosilicate corrected) } \\
\hline Puerto Rico & 1 & Granite & $1.00^{\mathrm{d}}$ & -2.2 & Kaolinite & -3.2 \\
\hline $\begin{array}{l}\text { Mungo, } \\
\text { Cameroon }\end{array}$ & 2,3 & Basalt & 1.11 & -1.95 & $\begin{array}{l}\text { Allophane and kaolinite } \\
\text { group }\end{array}$ & -3.06 \\
\hline Black Forest, & 4,5 & Sandstone & 0.57 & -0.57 & Vermiculite & -1.14 \\
\hline Germany & & Paragneiss & 0.53 & -0.72 & $\begin{array}{l}\text { Vermiculite (potentially } \\
\text { inherited) }\end{array}$ & -1.25 \\
\hline Anhui, China & 6 & Granite & 1.5 & -1.1 & Kaolinite & -2.6 \\
\hline $\begin{array}{l}\text { Mule Hole, } \\
\text { India }\end{array}$ & 7 & Gneiss & $0.90 \pm 0.48$ & $-1.30 \pm 0.03$ & Kaolinite & $-2.20 \pm 0.49$ \\
\hline \multirow[t]{4}{*}{ Iceland $^{\mathrm{e}}$} & 8 & Basalt & $0.1 \pm 0.26$ & $-1.67 \pm 0.35$ & Allophane and kaolinite & $-1.77 \pm 0.42$ \\
\hline & & Basalt & $0.55 \pm 0.48$ & $-1.2 \pm 0.32$ & & $-1.74 \pm 0.58$ \\
\hline & & Basalt & $0.17 \pm 0.27$ & $-1.15 \pm 0.11$ & & $-1.32 \pm 0.29$ \\
\hline & & Basalt & $0.28 \pm 0.18$ & $-0.86 \pm 0.24$ & & $-1.14 \pm 0.3$ \\
\hline
\end{tabular}

Erodosequence sites from this study are supplemented with literature data. Clay size fraction data from this study are corrected for primary mineral contribution (see main text, Table 4, and Appendix B for details); those from elsewhere are not. Kaolinite group clays have systematically greater fractionations than other clays indicative of less intense weathering regimes. a) Smectite and other 2:1 clay minerals reported from nearby on similar parent material in Egli, Mirabella, and Sartori (2008) and Egli, Mirabella, and Fitze (2001). b) Kaolinite is the only clay mineral occurring in sufficient quantities to be detected by the XRD analyses of Uhlig and others (2017), a conclusion corroborated by Dahlgren and others (1997). c) Kaolinite, along with gibbsite and goethite reported as the dominant secondary minerals by Behrens (2018) - kaolinite is the only Si bearing phase. d) Solution $\delta^{30} \mathrm{Si}$ taken as the average of four stream water and two soil water samples. e) Solution $\delta^{30} \mathrm{Si}$ values derive from soil water, not stream water. References: 1: Ziegler and others (2005c); 2: Opfergelt and others (2009); 3: Opfergelt and others (2010); 4: Steinhoefel and others (2011); 5: Steinhoefel and others (2017); 6: Yang and Zhang (2019); 7: Riotte and others (2018); 8 Opfergelt and others (2017).

achieved. Instead, a unidirectional kinetic isotope fractionation must be involved at some stage during clay formation. Note also that some relatively high $\delta^{30} \mathrm{Si}$ clays extracted from sandstone aquifer sediments (Georg and others, 2009) fit with this concept: the water-sediment interaction time may be so long in these systems that the clays have time to at least partially isotopically re-equilibrate with the solution. Overall, the data require a net kinetic discrimination against the heavier isotopes of Si during clay formation.

Our data and the available literature data suggest that different clay mineral groups have distinct $\mathrm{Si}$ isotope fractionation factors associated with their formation. With the exception of Icelandic sites formed from basalts, kaolinite Si isotope fractionations cluster around $\varepsilon_{\text {prec }}$ of $-3 \%$, while the formation of less desilicified 2:1 clays, including smectites and vermiculites, are closer to $-1 \%$. Note that this conclusion refers to the fractionation factor itself (\#3 in fig. 1), and not to how mass-balance effects (\#2 in fig. 1) control how it might be expressed. Might part of the explanation for the variable fractionation lie in the mechanism of their formation?

Previous work (Geilert and others, 2014; Oelze and others, 2014; Roerdink and others, 2015) shows that $\mathrm{Si}$ isotope fractionation during the laboratory precipitation of simple phases is rate dependent. This has been interpreted as competition between two endmember isotope effects in the context of a surface reaction kinetic model 


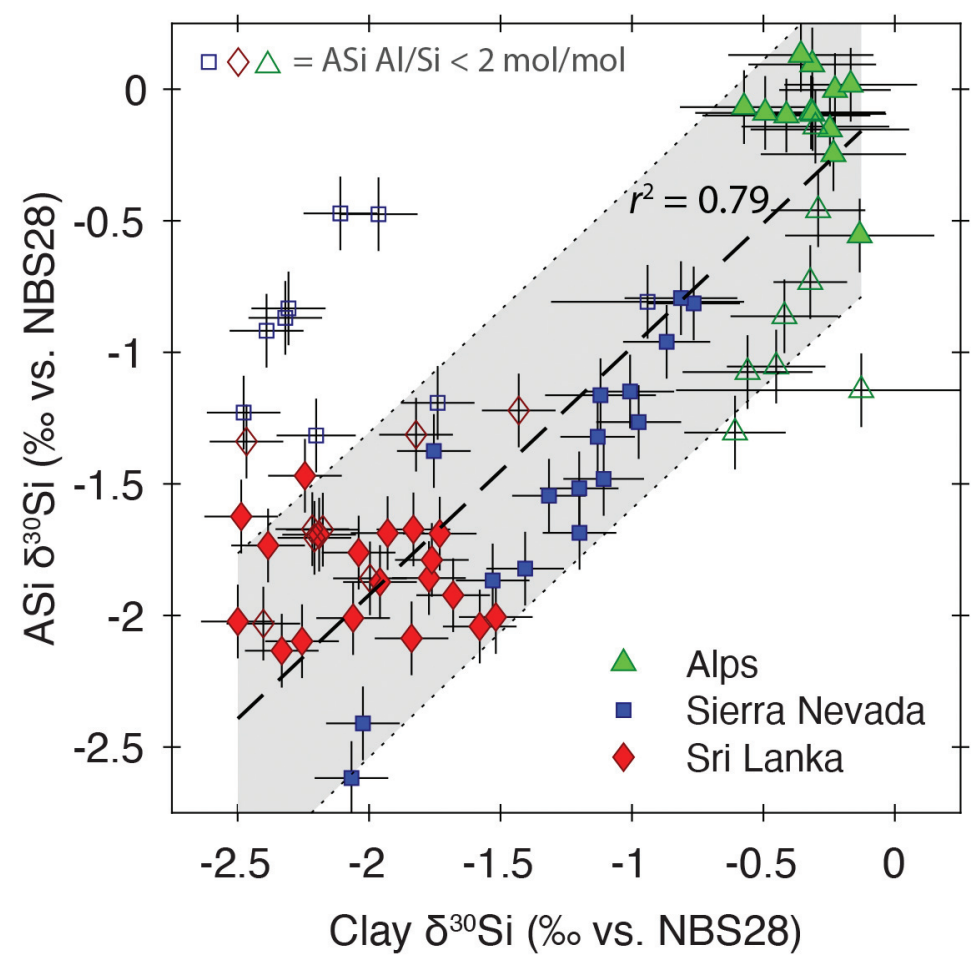

Fig. 6. Comparison between clay size fraction (primary mineral contribution corrected; see Appendix $\mathrm{B}$ and table 4) and amorphous $\mathrm{Si}$ fraction ( $\mathrm{NaOH}$ leach) $\delta^{30} \mathrm{Si}$ values from soil and saprolite samples. Open symbols denote samples with $\mathrm{NaOH}$ leach $\mathrm{Al} / \mathrm{Si}<2 \mathrm{~mol} \mathrm{~mol}^{-1}$ (see main text for details). The significance of the general correspondence between clay-size and amorphous silica fractions is i) that it adds support to the hypothesis that clay minerals form from an amorphous precursor (Behrens and others, 2015 ), and ii) suggests that clays inherit their $\delta^{30} \mathrm{Si}$ signature from this precursor (Oelze and others, 2014). Across all three study-sites, a regression of the high $\mathrm{Al} / \mathrm{Si}$ samples $\mathrm{ASi} \delta^{30} \mathrm{Si}$ on the clay $\delta^{30} \mathrm{Si}$ values (black dashed line) yields a strong correlation $\left(r^{2}=0.79 ; \mathrm{p}<0.001\right)$.

(DePaolo, 2011). Kinetic fractionation tends to deplete the forming solid in ${ }^{30} \mathrm{Si}$, while equilibrium fractionation tends to have a much smaller depletion or even slight enrichment in ${ }^{30} \mathrm{Si}$, depending on the Si bonding environment of the phase being considered. The consistent depletion in ${ }^{30} \mathrm{Si}$ in clays led Oelze and others (2014) to infer that clay minerals inherit a kinetically derived signature from an amorphous precursor, and are then slow to re-equilibrate their Si according to their equilibrium fractionation factor. The slow re-equilibration thus explains the discrepancy between natural samples and the predictions based on equilibrium fractionation factors (see above). Note that the formation of crystalline clay minerals from an Al-rich amorphous precursor is consistent with the Gay-Lussac-Ostwald step rule, which requires that the first phase to form will be the one that causes the least reduction in solute activity.

In our three sites, the amorphous fraction and the clay fraction $\mathrm{Si}$ isotope compositions correlate (fig. 6), although some Sierra Nevada samples deviate from this trend (discussed below). This overall correlation suggests that a potential explanation for the variable $\varepsilon_{\text {prec }}$ (table 7 ) is the magnitude of the kinetic isotope fractionation into the amorphous precursor. These phases are operationally targeted by the $\mathrm{NaOH}$ leach and are aluminium rich, as seen elsewhere (Barão and others, 2015). The two sites with the lowest $\delta^{30} \mathrm{Si}$ clay-size separates (Sri Lanka and Sierra Nevada; table 2) 
also have higher mean amorphous silica fraction molar $\mathrm{Al} / \mathrm{Si}$ ratios: 3.40 and 3.84, respectively, compared to 2.21 for the Alps (see supporting Data Tables in Frings and others, 2021a). This leads us to suggest a role for aluminium in setting Si isotope fractionation during clay mineral formation.

Interestingly, the samples in figure 6 that deviate most from the 1:1 line are also those with lowest $\mathrm{Al} / \mathrm{Si}$ ratio in the $\mathrm{NaOH}$ leach (data in supporting Data Tables $\mathrm{S} 1-$ S3, Frings and others, 2021a). In the Critical Zone, there are at least two sources of amorphous $\mathrm{Si}$ that we assume are targeted with an $\mathrm{NaOH}$ solution. First, there is the Al-rich amorphous phases that are thought to occur during many silicate weathering reactions (Hellman and others, 2012; Behrens and others, 2015). These likely form as mineral surface layers during silicate dissolution-reprecipitation reactions. The second source is phytolith $\mathrm{Si}$, and other biogenically formed amorphous Si phases. Barão and others (2015) show how the $\mathrm{Al} / \mathrm{Si}$ ratio of the $\mathrm{NaOH}$ leach is itself diagnostic of the source of the $\mathrm{ASi}$. Low $\mathrm{Al} / \mathrm{Si}$ is indicative of a biogenic origin, while high $\mathrm{Al} / \mathrm{Si}$ indicates a pedogenic origin. Thus, the low $\mathrm{Al} / \mathrm{Si}$ samples that deviate from the 1:1 line in a plot of $\mathrm{NaOH}$ leach $\delta^{30} \mathrm{Si}$ vs. clay size fraction $\delta^{30} \mathrm{Si}$ (fig. 6) might in some cases reflect a phytolith pool that is not a direct clay precursor. This is not always the case, however. A subset of Sierra Nevada samples in figure 6 have low $\mathrm{NaOH}$ leach $\mathrm{Al} / \mathrm{Si}\left(\leq 2 \mathrm{~mol} \mathrm{~mol}^{-1}\right)$, but derive from the deep Balsam saprolite profile (data in supporting table S2). We assume that there is not a substantial pool of phytolith $\mathrm{Si}$ at several metres depth in the regolith. Why this subset of samples has lower $\mathrm{Al} / \mathrm{Si}$ in the $\mathrm{NaOH}$ leach is unclear, but lends credence to the idea that the relative abundances of $\mathrm{Al}$ and $\mathrm{Si}$ influence $\mathrm{Si}$ isotope fractionation.

Further evidence for the role of aluminium is provided by the correlation between $\varepsilon_{\text {prec }}$ and individual clay sample $\mathrm{Al} / \mathrm{Si}$ (fig. 7) that is consistent among the three sites. Here, the fractionations are derived from a rearrangement of equation (2), with a definition of $f_{s e c}^{S i}$ coming from equation (5):

$$
\varepsilon_{\text {prec }}=\frac{\delta_{\text {sec }}-\delta_{\text {parent }}}{f_{\text {sec }}^{S i}}=\frac{\delta_{\text {sec }}-\delta_{\text {parent }}}{(\mathrm{Al} / \mathrm{Si})_{\text {parent }}{ }^{*}}
$$

where $(\mathrm{Al} / \mathrm{Si})_{\text {parent* }}$ is the $\mathrm{Al} / \mathrm{Si}$ ratio of bulk bedrock corrected for Si hosted in quartz, assuming that the quartz does not provide $\mathrm{Si}$ (fig. 5). The ratio of $\mathrm{Al} / \mathrm{Si}$ ratios in the denominator of equation (6) gives the reaction stoichiometry (that is, $f_{\text {sec }}^{S i}$, see eq 5 ). Equation (6) therefore allows the derivation of field-derived fractionation factors without knowing the dissolved Si composition. This approach is distinct from, but complementary to, the values presented in table 6 and table 7 derived from isotope differences. It is similar to how clay fractionation factors can be inferred from for example, $\mathrm{Si} / \mathrm{Na}$ ratios and $\delta^{30} \mathrm{Si}$ in river water and rock, without measuring the $\delta^{30} \mathrm{Si}$ of the clay itself (for example, Hughes and others, 2013). As above, equation (6) yields the fractionation itself (\#3 in fig. 1), and not its expression (that is, after accounting for the mass-balance control, \#2 in fig. 1). The fractionation derived from equation (6) differs in assumptions to that derived from an isotope difference (table 7 ), but yields reassuringly similar values. Elsewhere, others have made similar observations: Yang and Zhang (2019) show that $\delta^{30} \mathrm{Si}$ of the clay fraction in soils formed above a granite in a monsoonal region are negatively correlated with free $\mathrm{Al}$ concentrations. If $\mathrm{Al}$ availability is the proximate cause, what is the mechanism? Below, we investigate two possibilities.

Aluminium might be influencing $\mathrm{Si}$ isotope fractionation by altering the reaction pathways, that is, the activated complex of Transition State Theory (TST). There is a growing body of literature emphasizing that kinetic isotope fractionations are 


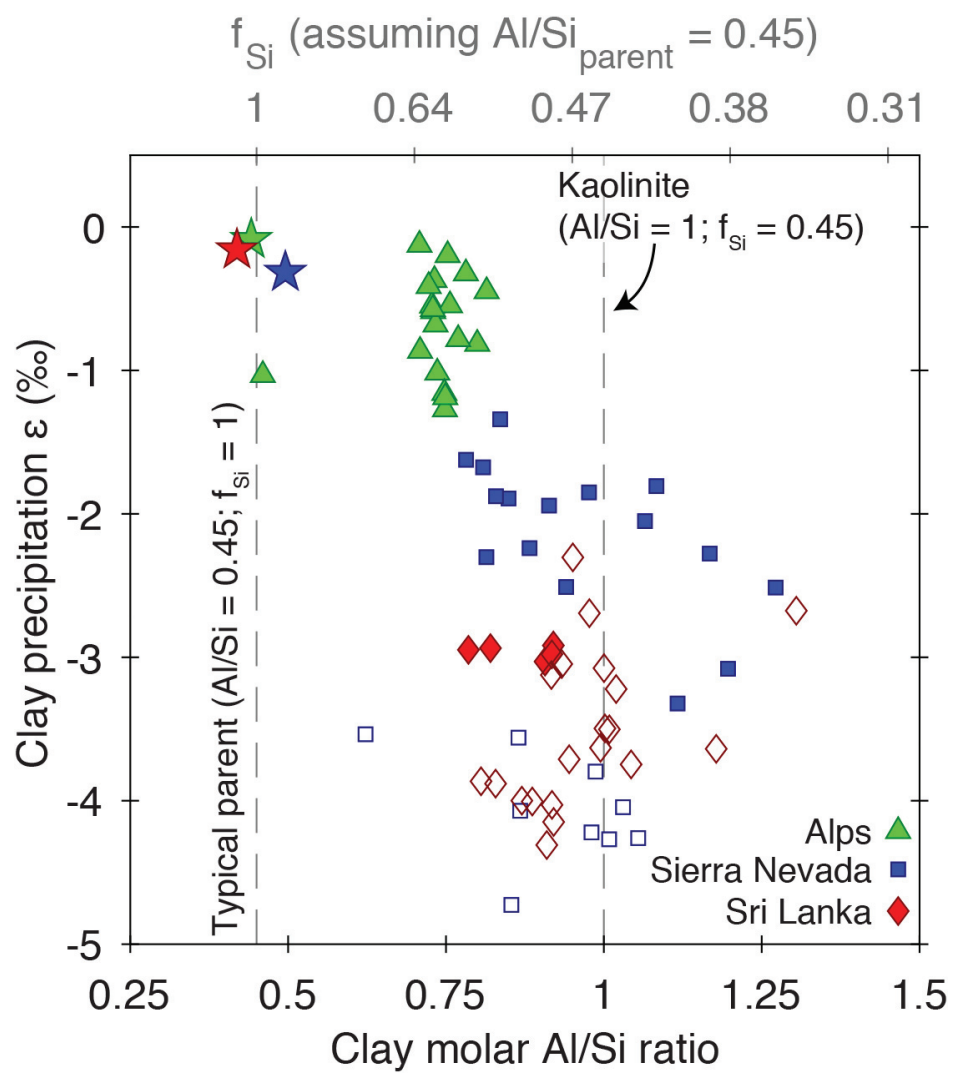

Fig. 7. Relationship between clay size fraction $\mathrm{Al} / \mathrm{Si}$ ratio and the ${ }^{30} \mathrm{Si} /{ }^{28} \mathrm{Si}$ isotope fractionation $\varepsilon$ (calculated from eq 6) associated with clay mineral formation. Filled symbols are soil samples, open symbols are saprolite samples. Stars indicate quartz-corrected parent rock. Vertical dashed lines illustrate parent material $\left(\mathrm{Al} / \mathrm{Si} \approx 0.45\right.$ for the non-quartz component of a typical granitoid rock, where $\left.f_{\text {sec }}^{S i}=1\right)$ and a kaolinite-type clay mineral $\left(\mathrm{Al} / \mathrm{Si}=1\right.$, thus $f_{\mathrm{sec}}^{S i}=0.45$; see also table 5$)$. The fractionations are calculated as the ratio of isotope difference between clay and (bulk) rock $\delta^{30} \mathrm{Si}$ to an estimate of $f_{\text {sec }}^{S i}$ derived from $\mathrm{Al} / \mathrm{Si}$ ratios (eq 6).

mechanism-dependent. For example, within the context of calcite crystallization, Nielsen and others (2012) infer that the magnitude of Ca kinetic isotope fractionation should vary with the stoichiometry of the solution the calcite precipitates from. Similarly, Joe-Wong and others (2019) show experimentally how the magnitude of $\mathrm{Cr}$ kinetic isotope fractionation increases as a function of the thermodynamic driving force (the standard free energy of reaction). These observations are consistent with the different kinetic isotope fractionations apparent during the adsorption of Si onto gibbsite at various solution $\mathrm{Al} / \mathrm{Si}$ ratios (Oelze and others, 2015). Kinetic isotope fractionations are in principle feasible to attain from ab initio calculations, but in practice the challenge is to define the transition state reactants pass through before the final product. The few calculations that have been made for Si isotopes (He and Liu, 2015; He and others, 2016) emphasize that estimates of the final fractionation factor for a given reaction can vary by more than $10 \%$ in some cases, depending on the transition state complex used in the calculation.

Alternatively aluminium may alter $\mathrm{Si}$ isotope fractionation factors by influencing reaction rates for any given reaction pathway. Within the framework of a surface kinetic model, DePaolo (2011) shows how isotope or trace-element fractionation into a 
precipitating solid is a function of reaction rate, reflecting the balance between competing isotope fractionations associated with the forward and backward reactions. The relevance of the surface kinetic model for $\mathrm{Si}$ isotope fractionation in clays is given by Yang and Steefel (2008), who present experimental evidence that the precipitation rate of kaolinite in flow-through reactors is a linear function of $\Delta \mathrm{G}$, the Gibbs free energy of reaction. $\Delta \mathrm{G}$ is itself is a function of aqueous $\mathrm{Al}$ and $\mathrm{Si}$ concentrations. This conclusion is also corroborated by amorphous $\mathrm{SiO}_{2}$ precipitation experiments (Geilert and others, 2014). Further exploring the role of Al geochemistry could provide a framework linking Si mobility, clay mineralogy and $\mathrm{Si}$ isotope systematics.

\section{Si Isotopes as a Proxy For Present and Past Weathering Intensity}

We show above that $\mathrm{Si}$ isotope ratios in secondary clays reflect a combination of the fractionation factors and net weathering reaction stoichiometry. Opfergelt and Delmelle (2012) have demonstrated that the Si isotope composition of bulk soils is a good proxy for the soil weathering intensity, that is, the fraction of mass-loss accomplished chemically. The Opfergelt and Delmelle (2012) compilation was dominantly basaltic and uses the Chemical Index of Alteration (CIA) as a proxy for weathering intensity (W/D, see above). CIA broadly traces mobile element loss, and is defined as $\left(\mathrm{Al}_{2} \mathrm{O}_{3} /\left(\mathrm{Al}_{2} \mathrm{O}_{3}+\mathrm{CaO}+\mathrm{Na}_{2} \mathrm{O}+\mathrm{K}_{2} \mathrm{O}\right) \times 100\right.$ (Nesbitt and Young, 1982). We show here that the granitic catchments of the Alps, Sierra Nevada, and Sri Lanka sites exhibit the same pattern (fig. 8) as the Opfergelt and Delmelle (2012) compilation. There is a negative relationship between CIA and bulk regolith $\delta^{30} \mathrm{Si}$. This relationship is relatively easy to explain as binary mixing. As a soil or saprolite weathers, the ratio of primary silicate minerals (high $\delta^{30} \mathrm{Si}$ ) to secondary (alumino) silicate minerals (low $\delta^{30} \mathrm{Si}$ ) decreases. This is similar to the observation made for lithium isotope ratios in fine-grained river sediment by Dellinger and others (2017). In our data, this highweathering intensity end member is represented by the Sri Lanka site, where the mineralogy of soils is dominated by quartz and kaolinite (fig. 5). At low-weathering intensity sites like the Alps, clays formed are both less ${ }^{30} \mathrm{Si}$ depleted and less abundant, so the $\mathrm{Si}$ isotope budget in these settings will be dominated by the unweathered primary minerals. The granitic sites presented here define an array that plots slightly above the basaltic sites making up the majority of the previous data (Opfergelt and Delmelle, 2012). This is likely because even at CIA $=100$, most soils formed above granitoid rocks will contain a substantial quartz component, which is not the case for basaltic settings. Overall, the relationship between bulk soil $\delta^{30} \mathrm{Si}$ and weathering intensity is therefore best understood as simple mixing between high and low $\delta^{30} \mathrm{Si}$ endmembers.

Recently, Bayon and others (2018) have shown that the $\delta^{30} \mathrm{Si}$ of the clay-size fraction (in their case, $<4 \mu \mathrm{m}$ ) of river suspended sediment also correlates strongly with weathering intensity in 50 global rivers. This opens the door to the use of $\mathrm{Si}$ isotopes in dissolved $\mathrm{Si}$ or in clays as a (palaeo)weathering-intensity proxy. In sediment records, bulk elemental geochemistry is hard to relate directly to weathering intensity of the landscape that produced the sediment. This difficulty arises because transport and deposition of sediments also control on sediment geochemistry (via size, shape and density effects on hydrodynamics) (Frings, 2019). But within the clay-size fraction, there is much less potential for biases induced by grain hydrodynamic properties. If the clay fraction reflects the bulk sample weathering intensity, there is potentially a powerful and novel tool for reconstructing past weathering regimes. In figure 9, we show that this is the case: clay-size fraction $\delta^{30} \mathrm{Si}$ is a proxy for the fractional base cation $\left(\mathrm{Ca}^{2+}, \mathrm{Mg}^{2+}, \mathrm{K}^{+}\right.$ and $\mathrm{Na}^{+}$) loss relative to parent rock (see Appendix E). We use this as a proxy for weathering intensity (W/D) to account for compositional differences in bedrock in a way that the CIA metric does not, and to emphasise the remaining $\mathrm{CO}_{2}$ consumption potential 


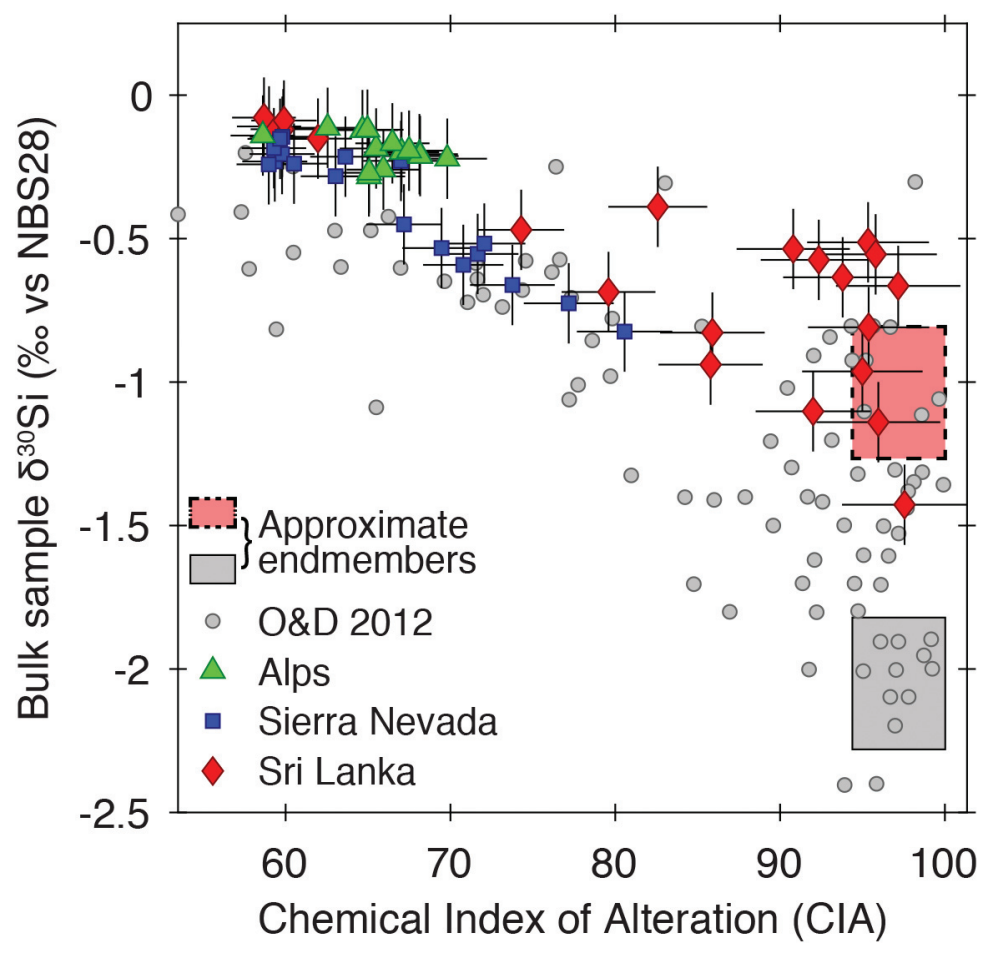

Fig. 8. The utility of silicon isotope ratios as a weathering-intensity proxy, as shown by the silicon isotope composition of bulk soils, as a function of soil Chemical Index of Alteration (CIA). CIA is a proxy for weathering intensity $\mathrm{W} / \mathrm{D}$, and is defined as $\left(\mathrm{Al}_{2} \mathrm{O}_{3} / \mathrm{Al}_{2} \mathrm{O}_{3}+\mathrm{CaO} *+\mathrm{Na}_{2} \mathrm{O}+\mathrm{K}_{2} \mathrm{O}\right) \times 100$ (Nesbitt and Young, 1982), with $\mathrm{CaO}^{*}$ indicating Ca hosted in silicate minerals only. The more weathered a soil is (the more it has lost the mobile elements $\mathrm{Ca}, \mathrm{Na}$ and $\mathrm{K}$ ), the more CIA tends towards 100 . The trend towards lower bulk soil and saprolite $\delta^{30} \mathrm{Si}$ with increasing CIA arises from mixing between primary rock forming minerals (high $\delta^{30} \mathrm{Si}$, high $\mathrm{Ca}, \mathrm{Na}, \mathrm{K}$ ) and secondary minerals (low $\delta^{30} \mathrm{Si}$, low $\mathrm{Ca}, \mathrm{Na}, \mathrm{K}$ ). Shaded boxes represent approximate endmembers for granitoid rock and basaltic rock (red and gray, respectively) as $\mathrm{CIA} \rightarrow 100$. The difference results from the much greater concentration of quartz in granitoid rock, which influences bulk $\delta^{30} \mathrm{Si}$ but not CIA. See main text for details. O\&D $2012=$ Opfergelt and Delmelle (2012).

of a soil or sediment sample. Dellinger and others (2017) observe a similar relationship between catchment $\mathrm{W} / \mathrm{D}$ and the lithium isotope composition of fine-grained river sediment, which they largely interpret as mixing between primary minerals and secondary minerals, that is, a similar interpretation as for figure 8 . Here, we performed a clay-size fraction separation. We believe the separation of secondary clays and primary minerals was successful (see Appendix B), while Dellinger and others (2017) use only the $<63$ $\mu \mathrm{m}$ fraction of river surface sediments. The relationship in figure 9 is thus hard to explain within the endmember mixing concept for bulk soils described above (fig. 8). Within the context of the three factors discussed in this manuscript (fig. 1), the simplest explanation is a combination of a fractionation factor that scales with $\mathrm{Al}$ availability, and the variable expression of this fractionation as governed by net weathering reaction stoichiometry, and therefore weathering intensity.

\section{CONCLUSIONS}

We present detailed silicon isotope budgets for three granitic weathering profiles falling along a gradient of erosion rate (an "erodosequence"), and thus time material spends in the weathering zone and overall weathering intensity. The three sites have similar parent material $\delta^{30} \mathrm{Si}$ values around $-0.15 \%$, typical of granitoid rocks. Yet the 


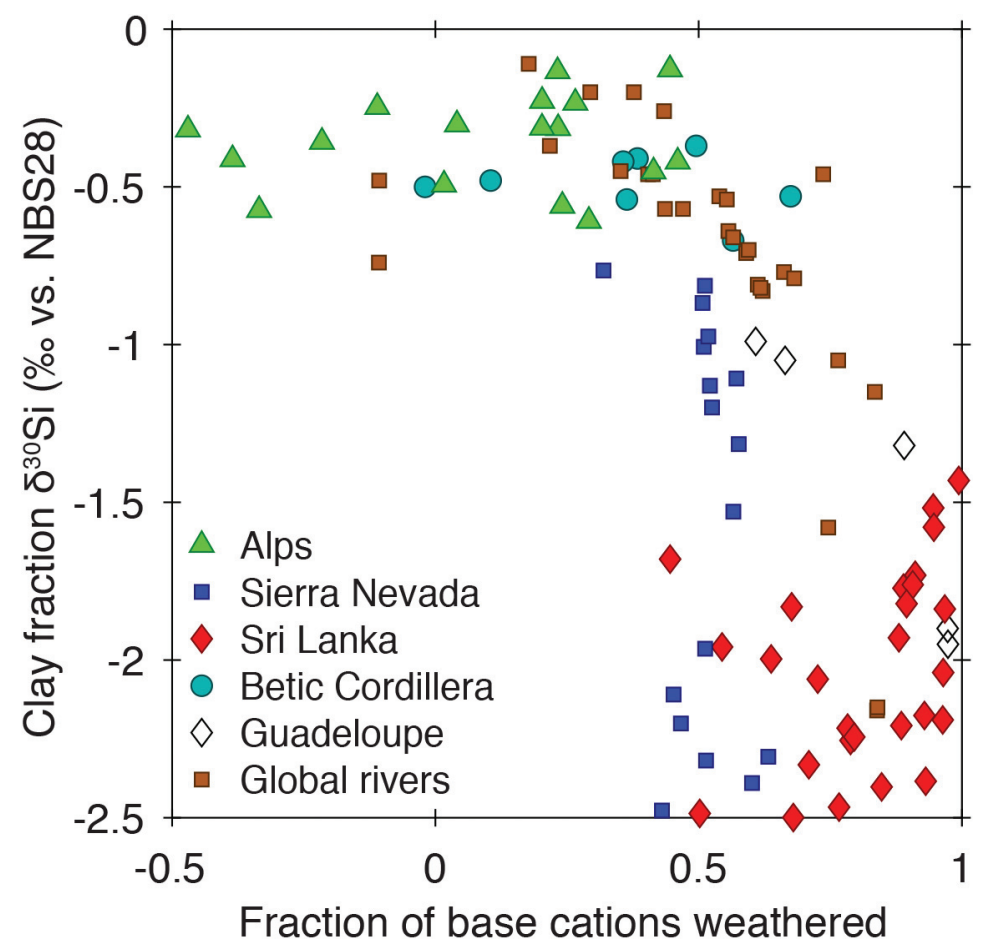

Fig. 9. The Si isotope composition of the clay-size fraction (after correction for primary mineral contributions for Alps, Sierra Nevada, and Sri Lanka samples; see table 4), against the fraction of silicatehosted base cation equivalents lost to weathering from the bulk sample (considering $\mathrm{Mg}^{2+}, \mathrm{Ca}^{2+}, \mathrm{K}^{+}$and $\mathrm{Na}^{+}$only, see Appendix E). Here, 1 implies complete silicate-cation loss from the soil/saprolite and 0 implies the same cation content as bedrock. For the for Alps, Sierra Nevada, and Sri Lanka samples, (considering $\mathrm{Ca}, \mathrm{Mg}, \mathrm{N}$ and $\mathrm{K}$, see Appendix $\mathrm{E}$ ) is calculated using the element mass transfer coefficient $\tau_{Z r}^{X}$, with full details given in von Blanckenburg and others, 2021). Also shown is data (not primary mineral corrected) from Ameijeiras-Mariño and others (2017) in the Spanish Betic Cordillera which developed over a mica-schist. This likely includes a large fraction of primary rock-forming phyllosilicates. Basalt soil clays from Guadeloupe are also plotted from Opfergelt and others (2012). In both cases, the cation loss from bulk soil is indexed directly to the reported parent material. The river sediment clay fraction data of Bayon and others (2018) is also shown. Here, cation loss is derived from reported silt size fraction (4-63 $\mu \mathrm{m}$ ) geochemistry (assuming this is representative of total eroded material; Bayon and others, 2015) normalised to an average upper continental crust (UCC) composition from Rudnick and Gao (2003). The trend towards decreasing clay $\delta^{30} \mathrm{Si}$ with increasing weathering intensity is best explained by a combination of larger magnitude fractionation factor (\#3 in fig. 1) and greater expression (\#2 in fig. 1) for clays forming at high weathering intensity.

isotope ratios of the phases produced from bedrock-derived Si (including river waters, clays, amorphous phases and plant material) differ substantially within and between the three sites. Here, we condense these Si isotope distributions to the simplest possible interpretative framework, comprising three parameters: 1) the isotope ratio of an initial ('parent') phase, 2) the relative partitioning of this initial material between one or more secondary phases, and 3) the fractionation factor(s) associated with this partitioning. The data presented here shows how all three vary along our erodosequence in a way that is generalisable to the suite of 'novel' metal(loid) stable isotope systems:

- At each site, the primary minerals that comprise the bulk parent rock span a large range of isotope ratios. This means that if one is preferentially dissolved relative to another, the isotope ratio of the initial material can differ from the bulk rock by a 
non-negligible amount. For silicon, this can conceivably be by $0.5 \%$ or more (fig. 4) but in most cases is unlikely to induce more than a few tenths of a permil deviation from a bulk rock composition.

- The partitioning of an element between solute and secondary phases is governed by the net weathering reaction stoichiometry, which itself reflects weathering intensity, and controls how much a fractionation factor can be expressed. For $\mathrm{Si}$, forming kaolinite instead of a smectite-group clay means a factor of two or more difference in how much $\mathrm{Si}$ is lost.

- The fractionation factor associated with secondary phase formation is not constant, but varies with the mineralogy of the phase being formed. For $\mathrm{Si}$, this varies between $-3 \%$ o to $-1 \%$, and may be related to aluminium geochemistry that affects the rate and/or pathways of clay formation or its amorphous precursor. For plant $\mathrm{Si}$ uptake, the $\mathrm{Si}$ isotope fractionations are similar at the three sites.

Future work could experimentally, empirically, and theoretically investigate the links between $\mathrm{Al}$ geochemistry, silicate dissolution and precipitation rates, and $\mathrm{Si}$ isotope fractionation to yield a more mechanistic understanding of why fractionation factors differ between clay minerals. The data and interpretations presented here contribute to the framework needed to quantitatively interpret silicon isotope distributions in terrestrial ecosystems, or to quantitatively reconstruct weathering intensity from $\delta^{30} \mathrm{Si}$ of phases preserved in sedimentary archives. A companion paper (Frings and others, 2021b) focuses on one application of this dataset: what knowledge of silicon isotope partitioning can contribute to an understanding of ecosystem nutrient budgets.

\section{ACKNOWLEDGMENTS}

We thank Julien Bouchez for discussions and review of an earlier version of this manuscript. We thank Kevin Norton for the introduction to the Swiss Alps field site, Jeannie Dixon for the introduction to the Sierra Nevada field site, and Tilak Hewawasam for the introduction to the Sri Lanka field site. Jan Schüssler, Jeannie Dixon, Julien Bouchez and Tilak Hewawasam helped with sampling. Jutta Schlegel and Josefine Holtz are thanked for assistance with analyses at the HELGES laboratory at GFZ-Potsdam. We are grateful to Damien Cardinal and an anonymous reviewer for their thoughtful and constructive reviews of this manuscript.

\section{APPENDICES}

Appendix A: Silicon Concentrations in Critical Zone Compartments

Figure A1 shows the Si concentrations of various Critical Zone compartments at the Alps, Sierra Nevada and Sri Lanka sites.

\section{Appendix B: Composition and Contamination of the Clay-Size Fraction}

All clay separation protocols target $\mathrm{a}<2 \mu \mathrm{m}$ size fraction rather than a true mineralogical fraction. The clay size separates might thus contain primary minerals (including quartz or phyllosilicates such as micas). A first-order assessment of the extent to which our separates are true secondary clays can be made via their elemental composition. In Sri Lanka, the molar $\mathrm{Al} / \mathrm{Si}$ ratio of the clay fraction from soil samples is $1.02 \pm 0.28(1 \sigma)$, in the Alps $0.56 \pm 0.08$ and in Sierra Nevada $0.85 \pm 0.12$. For reference, kaolin-group minerals have $\mathrm{Al} / \mathrm{Si}$ of $\sim 1$, smectite group minerals $\sim 0.5$ and the primary rock forming minerals $<0.5$ (table 3 in the main text). In Sri Lanka, the clay mineralogy is dominated by kaolinite, with some gibbsite towards the top of the profile (Behrens and others, 2015). In Sierra Nevada, kaolinite is the only secondary 
mineral that was visible in bulk XRD spectra (Uhlig and others, 2017). Analyses from clay-size separates of soils overlying the same Dinkey Creek granodiorite also identified vermiculite, plus primary mica in sites at a similar elevation (Dahlgren and others, 1997). In the Swiss Central Alps glacial tills comprising granitic rock at similar

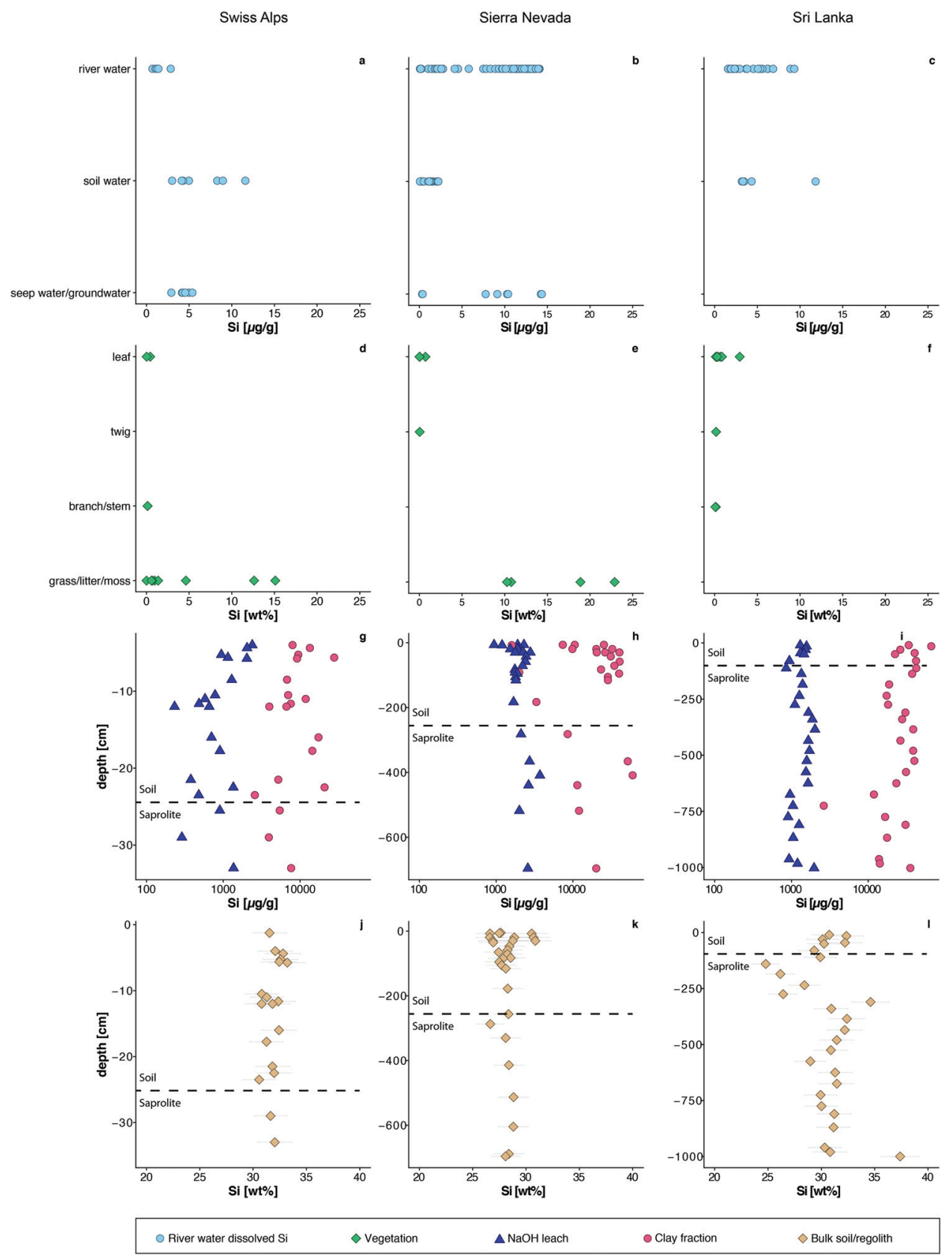

Fig. A1. Si concentrations $\left(\mu \mathrm{g} \mathrm{g}^{-1}\right)$ of bulk samples, clay size-fractions, amorphous Si leachates, plants, and water samples, at the three field sites. 

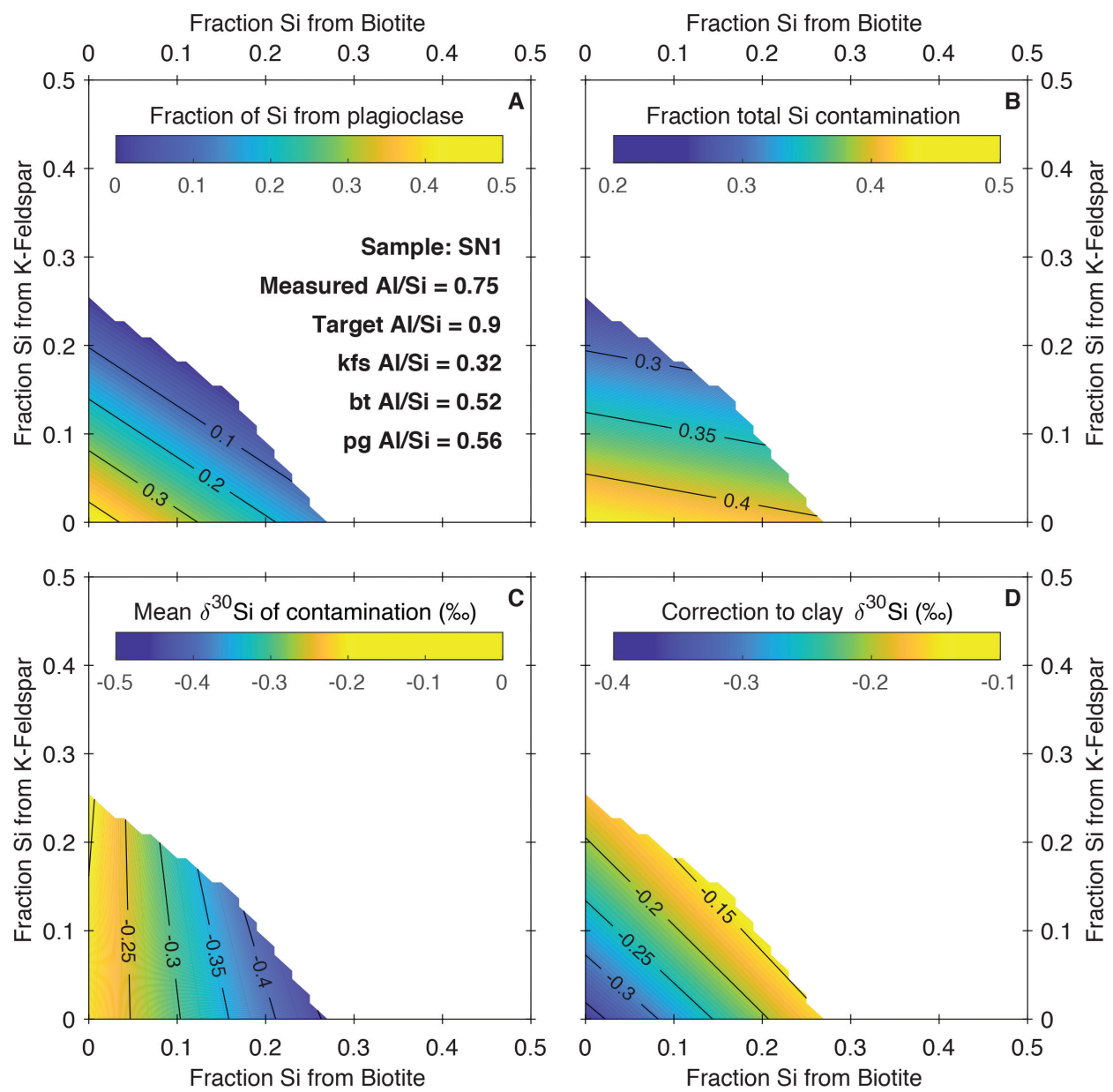

Fig. A2. Illustration of workflow to calculate how much the inclusion of primary minerals in the claysize fraction is biasing the measured $\delta^{30} \mathrm{Si}$ if the $\mathrm{Al} / \mathrm{Si}$ ratio of the secondary clays is known. Panel A shows the combinations of primary minerals that would mix with a clay with prescribed $\mathrm{Al} / \mathrm{Si}$ (in this example, 0.9 ) to yield the measured $\mathrm{Al} / \mathrm{Si}$ value (here, 0.75 ). The total contribution to clay-size fraction $\mathrm{Si}$ (Panel $\mathrm{B}$ ) is thus the sum of the individual mineral abundances, and is highest for the set of solutions with more high $\mathrm{Al} / \mathrm{Si}$ primary phases. Together with the weighted mean $\delta^{30} \mathrm{Si}$ of these minerals (Panel $\mathrm{C}$ ), the bias on the measured clay-size fraction $\delta^{30} \mathrm{Si}$ can be calculated from a simple mixing equation (that is, $\delta^{30} \mathrm{Si}_{\text {meas }}=\left(1-\sum f_{i}\right) \delta^{30} \mathrm{Si}_{\text {clay }}+\sum f_{i} \delta^{30} \mathrm{Si}_{\mathrm{i}}$. These figures show solutions to eq $\mathrm{S} 1$ when the fraction of $\mathrm{Si}$ from quartz is zero. Increasing quartz abundances decrease the contribution from the other primary phases but make a negligible impact on the magnitude of correction (Panel D) since they have similar $\delta^{30} \mathrm{Si}$. Mineral abbreviations: $k f s=\mathrm{K}-$ Feldspar; $b t=$ Biotite; $p g=$ Plagioclase.

elevations to our study sites produce smectites (Egli and others, 2001; Egli and others, 2008). At the erodosequence sites the 'expected' $\mathrm{Al} / \mathrm{Si}$ ratios are thus slightly higher than 1 in Sri Lanka (kaolinite + some gibbsite); slightly lower than 1 in Sierra Nevada (kaolinite + some vermiculite), and around 0.6 in the Alps (smectite group minerals). Therefore, we conclude that the $\mathrm{Al} / \mathrm{Si}$ ratios suggest a dominantly 'true' clay assemblage. The match between expected and observed $\mathrm{Al} / \mathrm{Si}$ ratios argues against the coincidental mixing of for example, quartz $(\mathrm{Al} / \mathrm{Si}=0)$ and gibbsite $(\mathrm{Al} / \mathrm{Si}=\infty)$ to produce a kaolinite-like $\mathrm{Al} / \mathrm{Si}$ ratio. In any case, this quartz-gibbsite mixing scenario is 

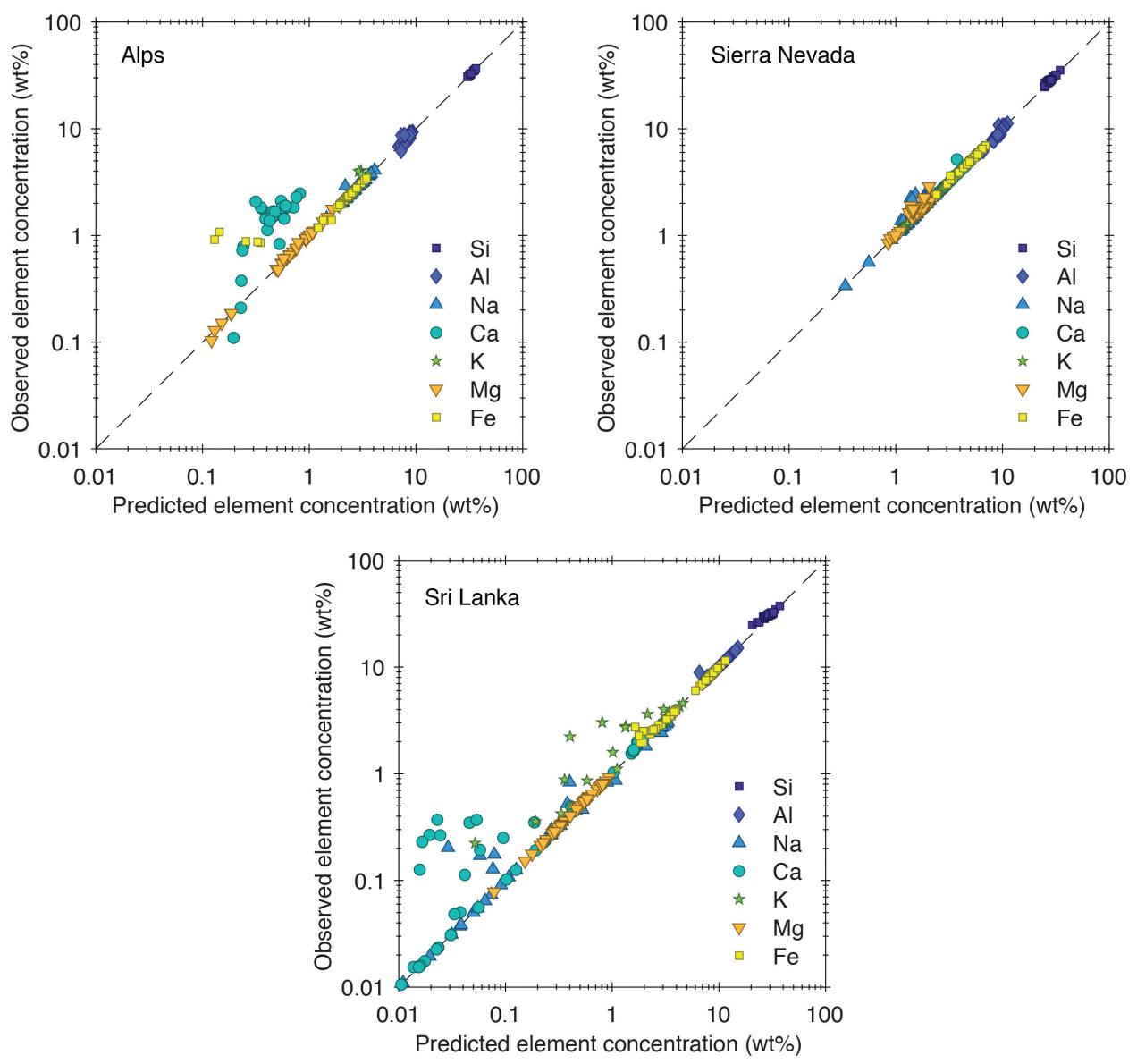

Fig. A3. A comparison between predicted element concentrations in bulk soil or saprolite samples derived from a mineral-specific mass-balance model, with measured element concentrations.

only plausible in Sri Lanka, since gibbsite is not observed to be forming in Sierra Nevada or the Alps.

Further evidence for the absence of primary minerals in the clay-size fraction comes from $\mathrm{Ca} / \mathrm{Si}$ and $\mathrm{Mg} / \mathrm{Si}$ ratios. These are low: $\mathrm{Ca} / \mathrm{Si}$ ratios average $<0.01,0.05$ and $0.02 \mathrm{~mol} / \mathrm{mol}$, and $\mathrm{Mg} / \mathrm{Si}$ ratios average $0.16,0.15$ and $0.03 \mathrm{~mol} / \mathrm{mol}$, in Sri Lanka, Sierra Nevada and the Swiss Alps, respectively. There are no trends in clay size fraction $\mathrm{Al} / \mathrm{Si}, \mathrm{Ca} / \mathrm{Si}, \mathrm{Mg} / \mathrm{Si}$ with depth in the regolith profiles, which might be expected to increase if clay abundance decreases with depth. Qualitatively, these compositions also suggest the clay size fraction dominantly comprises pedogenic clay minerals. This gives confidence that the measured $\delta^{30} \mathrm{Si}$ values reflect the newly formed secondary minerals rather than a mixture between new clays and primary phases.

Simple mass-balance approaches can more rigorously quantify the potential presence of primary phases and assess their potential impact on the measured clay $\delta^{30} \mathrm{Si}$. Here, we exploit the known clay mineralogy to assess and correct the clay size fraction $\delta^{30} \mathrm{Si}$ for primary minerals. This approach is based on the assumption that we know the $\mathrm{Al} / \mathrm{Si}$ ratio of the clay minerals that are forming. The workflow is illustrated for an 
example sample in figure A2. In an initial step (Panel A), mixtures of the primary phases quartz, K-feldspar, plagioclase and biotite, with formulae as given in table 3, are subtracted from the measured clay-size fraction chemical composition, until the $\mathrm{Al} / \mathrm{Si}$ ratio is equivalent to that expected (prescribed to be $0.7 \pm 0.1,0.9 \pm 0.1$ and $1.0 \pm 0.1$ for the Alps, Sierra Nevada, and Sri Lanka, respectively). In other words, the contours in figure A2A show solutions to the mixing equation:

$$
\left(\frac{A l}{S i}\right)_{\text {clay }}=\frac{\left(\frac{A l}{S i}\right)_{\text {meas }}-\sum f_{i}\left(\frac{A l}{S i}\right)_{i}}{\left(1-\sum f_{i}\right)}
$$

where $\left(\frac{A l}{S i}\right)_{c l a y}$ is the prescribed ratio, $\left(\frac{A l}{S i}\right)_{\text {meas }}$ is the measured ratio, $\left(\frac{A l}{S i}\right)_{i}$ is the ratio in phase $i$ (where $i$ can be quartz, plagioclase, feldspar or biotite), and $f_{i}$ is the contribution of Si from phase $i$ to the total clay-size fraction. Solutions to the mixing equation are ignored if they yield negative $\mathrm{Ca}, \mathrm{Mg}, \mathrm{K}$ or Fe concentrations. Then, the primary mineral abundances can be used to calculate the fraction of $\mathrm{Si}$ in the clay-size separate that comes from primary phases (Panel B). In turn, this can be used to calculate the mean $\delta^{30} \mathrm{Si}$ of these phases (Panel C, using mineral $\delta^{30} \mathrm{Si}$ values from table $3 /$ fig. 4). Finally, the magnitude of the correction for each solution to equation (S1) can be calculated from a simple mixing equation (Panel D). Making the simplifying assumption that all primary phases are equally likely to be found in the clay-size fraction (that is, all solutions to eq $\mathrm{S} 1$ are equally likely), and assuming the true clay $\mathrm{Al} / \mathrm{Si}$ ratio is 0.7 , 0.9 and 1.0 in the Alps, Sierra Nevada, and Sri Lanka, respectively, the results confirm a small Si contribution from primary minerals. In the Alps, $33 \pm 15 \%$ of $\mathrm{Si}$ is from primary phases, in Sierra Nevada $17 \pm 19 \%$, and in Sri Lanka $0.2 \pm 0.01 \%$. This yields minor corrections to the measured clay-size fraction $\delta^{30} \mathrm{Si}:+0.07 \pm 0.08 \%$ o (mean $\pm 1 \sigma$ ) in the Alps, $-0.20 \pm 0.26 \%$ in Sierra Nevada, and $0.00 \pm 0.01 \%$ in Sri Lanka. The overall magnitude of the correction is insensitive to the prescribed clay $\mathrm{Al} / \mathrm{Si}$ ratio - the mean correction magnitude differs by $<0.15 \%$ in absolute magnitude for prescribed $\mathrm{Al} / \mathrm{Si}$ ratios $0.1 \mathrm{~mol} / \mathrm{mol}$ higher or lower. The takeaway message is thus that the measured clay-size fraction $\delta^{30} \mathrm{Si}$ values are reasonably close approximations for the 'true' secondary clays that are present in the erodosequence sites.

To avoid making the assumption that all samples at every site have identical $\mathrm{Al}$ / Si ratios, and to avoid making judgements about which primary minerals are most likely to be found in the clay-size fraction, for the data shown in the main text we perform a correction that subtracts from each sample a primary mineral composite (that is, a mean of the composition of quartz, plagioclase, feldspar and biotite at each site). We assume that each sample contains our best estimate of the average amount of primary-mineral silicon for that site (that is, $33 \%, 17 \%$ and $0.2 \%$, in the Alps, Sierra Nevada and Sri Lanka, respectively; see above). In practical terms, this means that clay size fraction geochemistry (including $\delta^{30} \mathrm{Si}$ ) for samples from Sri Lanka is essentially unchanged, and only slightly adjusted in the Alps and Sierra Nevada.

\section{Appendix C: Inversion of Bulk Geochemical Composition to Obtain Mineral Abundances}

The aim is to calculate the proportion of individual minerals contributing to a bulk samples' geochemistry to derive an estimate of mineral loss relative to bedrock. This can be combined with mineral-specific $\delta^{30}$ Si determinations (see table 3 in the main text) to produce an estimate of the $\delta^{30} \mathrm{Si}$ of the Si initially released to solution $\left(\delta^{30} \mathrm{Si}_{\text {initial }}\right.$, \#1 in fig. 1). Previous work has used quantitative X-Ray Diffraction (XRD) in concert with $\mathrm{Zr}$ concentrations to infer mineral specific weathering rates (for example, Ferrier and others, 2010). Our approach here is similar, except we 
infer the mineral concentrations from a deconvolution of bulk geochemistry, reported as LOI-corrected concentrations in von Blanckenburg and others (2021) and in the supporting Data Tables (Frings and others, 2021a). This is achieved with a simple inverse mass-balance approach similar to that used to derive mineral contributions to stream-water chemistry (Price and others, 2005; Velbel and Price, 2007). We define a mass-balance equation for each of the major elements $\mathrm{Si}, \mathrm{Al}$, $\mathrm{Mg}, \mathrm{Ca}, \mathrm{Na}, \mathrm{K}$, and Fe:

$$
X_{b u l k}=\frac{\sum x_{i} X_{i} M_{i}}{\sum x_{i} M_{i}}
$$

where $\mathrm{X}$ is the element concentration in $\mathrm{g} / \mathrm{g}$ in the bulk sample and in mineral $i, x_{i}$ is the fractional contribution of mineral $i$ and $M_{i}$ is mass of one mole of mineral $i$, as calculated from the molar formulae in table 3 in the main text. Including the constraint that $\sum_{x}=1$, gives eight mass-balance equations. The contributions of five primary minerals (Plagioclase, K-feldspar, Biotite, Quartz and Pyroxene) and three secondary phases (a clay mineral, an iron oxide, and amorphous $\mathrm{Si}$ ) are calculated by optimising $x$ in order to minimise the root-mean-square-error (RMSE) between predicted and observed concentrations. We incorporate the constraints that $0 \leq x \leq 1$ for all phases, and that amorphous $\mathrm{Si} \leq 1 \mathrm{wt} \%$, based on our $\mathrm{NaOH}$ extractions (see Supplementary Data table S1, Frings and others, 2021a). This mass-balance is overconstrained: there is no exact solution. We use a global non-linear optimisation algorithm (Ugray and others, 2007) to find the best solution, implemented within Matlab 2020a. The algorithm utilizes a multi-start routine to find a global minimum. The mineral-specific elemental stoichiometries at each site are different, and are constrained by EDX measurements or mineral specific digestions (Main Text table 3). An ideal formula for goethite $(\mathrm{FeO}(\mathrm{OH}))$ is used for the iron-oxide phase, and is assumed to have $\mathrm{Si}$ adsorbed to its surfaces, Fe/Si set at $\sim 100$ after Delstanche and others (2009). The $\mathrm{Al} / \mathrm{Si}$ ratio of the amorphous phase is given by our $\mathrm{NaOH}$ extractions. The composition of the secondary clay is given at each site by the corrected clay-size fraction chemistry (Main Text table 4, full data in Supplementary Data table S1, Frings and others, 2021a), with the formulae as given in Main Text table 7. A Monte-Carlo (250 iterations) approach is used to assess uncertainties, by allowing the mineral element concentrations to vary by $\pm 10 \%$ and including a $\pm 10 \%$ error on the XRF element concentration measurements for bulk soil, saprolite and rock. Secondary phase concentrations are fixed at zero concentration for unweathered bedrock samples. For the Sri Lanka site, we modified this procedure to include radiogenic $\mathrm{Sr}$ isotope ratios from Hewawasam and others (2013), using the mineral specific ${ }^{87} \mathrm{Sr} /{ }^{86} \mathrm{Sr}$ ratios of Burton and O'Nions (1990). This made little difference to the results and is not considered further.

Figure 5 in the main text shows the results while figure A3 shows the model performance. In general, predicted and observed element concentrations match well, lending confidence to the results. In the Alps and Sri Lanka, predicted cation concentrations (mostly $\mathrm{Ca}, \mathrm{K}$, or Fe) are occasionally $\leq 1 \mathrm{wt} \%$ lower than observed. This may be due to inaccurate mineral compositional data, the presence of minor phases or dust particulates not considered, or mineral compositions that are not representative of all bedrock (for example, the granites and gneisses in the Alps will exhibit different mineral formulae; the same is true of the Dinkey Creek granodiorite and quartz diorite underlying the Sierra Nevada site). Nevertheless, the first-order observations are unlikely to change. 
Appendix D: Isotope Differences as Approximations for Isotope Fractionations

An isotope fractionation factor $\alpha$ for a process partitioning Si between phase A and $\mathrm{B}$ is defined as the ratio of two ratios:

$$
\alpha_{X}=\frac{R_{A}}{R_{B}}
$$

Where $\mathrm{R}$ is the ratio ${ }^{30} \mathrm{Si} /{ }^{28} \mathrm{Si}$. Both $\alpha$ and $\mathrm{R}$ are related to the more convenient permil equivalents $\varepsilon$ and $\delta$ :

$$
\begin{gathered}
\alpha_{X}=\frac{\varepsilon_{X}}{1000}+1 \\
R=\left(\frac{\delta}{1000}+1\right) \cdot R_{N B S}
\end{gathered}
$$

Substituting these expressions into equation (S3) and simplifying:

$$
\varepsilon_{X}=\frac{1000 \delta_{A}-1000 \delta_{B}}{\delta_{B}+1000}
$$

When $\delta_{B}$ and $\delta_{A}$ are much less than 1000, the expression simplifies to:

$$
\varepsilon_{X} \approx \delta_{A}-\delta_{B}
$$

As Bouchez and others (2013) show, this general approach is also valid for cases where two or more processes are removing an element from a single well-mixed pool.

\section{Appendix E: Cation Loss as a Proxy for Weathering Intensity}

We use an expression for the fractional cation equivalent loss as a proxy for weathering intensity, defined as:

$$
\sum \frac{-\rho_{X_{i}} \cdot \tau_{Z r}^{X_{i}} \cdot[X]_{r o c k, i}}{\rho_{X_{i}} \cdot[X]_{r o c k, i}}
$$

Where $\rho_{X}$ is the charge associated with a cation $\left(2^{+}\right.$for $\mathrm{Ca}$ and $\mathrm{Mg}, 1^{+}$for $\mathrm{Na}$ and $\mathrm{K}),[X]_{\text {rock }}$ is that cations concentration in the parent rock, $\tau_{Z r}^{X}$ is the zirconiumnormalised mass transfer coefficient for that element, and $i$ denotes $\mathrm{Na}, \mathrm{Ca}, \mathrm{K}$, and $\mathrm{Mg}$.

\section{REFERENCES}

Aguirre, A. A., ms, 2019, Applying Ge/Si Ratios to Trace Weathering Reactions Hydrologic Pathways and Coal Fly Ash Contamination in Watersheds Across the United States: Ithaca, New York, Cornell University, Ph. D. thesis, 210 p.

Ameijeiras-Mariño, Y., Opfergelt, S., Schoonejans, J., Vanacker, V., Sonnet, P., de Jong, J., and Delmelle, P., 2017, Impact of low denudation rates on soil chemical weathering intensity: A multiproxy approach: Chemical Geology, v. 456, p. 72-84, https://doi.org/10.1016/j.chemgeo.2017.03.007

Bales, R. C., Hopmans, J. W., O'Geen, A. T., Meadows, M., Hartsough, P. C., Kirchner, P., Hunsaker, C. T., and Beaudette, D., 2011, Soil moisture response to snowmelt and rainfall in a Sierra Nevada mixedconifer forest: Vadose Zone Journal, v. 10, n. 3, p. 786-799, https://doi.org/10.2136/vzj2011.0001

Barão, L., Vandevenne, F., Clymans, W., Frings, P., Ragueneau, O., Meire, P., Conley, D. J., and Struyf, E., 2015, Alkaline-extractable silicon from land to ocean: A challenge for biogenic silicon determination: Limnology and Oceanography: Methods, v. 13, n. 7, p. 329-344, https://doi.org/10.1002/lom3.10028 
Baronas, J. J., Torres, M. A., West, A. J., Rouxel, O., Georg, B., Bouchez, J., Gaillardet, J., and Hammond, D. E., 2018, Ge and Si isotope signatures in rivers: A quantitative multi-proxy approach: Earth and Planetary Science Letters, v. 503, p. 194-215, https://doi.org/10.1016/j.epsl.2018.09.022

Bateman, P. C., and Wones, D. R., 1972, Huntington Lake Quadrangle, central Sierra Nevada, California; analytic data: USGS Professional Paper 724-A, 17 p., https://doi.org/10.3133/pp724A

Bayon, G., Toucanne, S., Skonieczny, C., André, L., Bermell, S., Cheron, S., Dennielou, B., Etoubleau, J., Freslon, N., Gauchery, T., Germain, Y., Jorry, S. J., Ménot, G., Monin, L., Ponzevera, E., Rouget, M. L., Tachikawa, K., and Barrat, J. A., 2015, Rare earth elements and neodymium isotopes in world river sediments revisited: Geochimica et Cosmochimica Acta, v. 170, p. 17-38, https://doi.org/10.1016/j.gca .2015 .08 .001

Bayon, G., Delvigne, C., Ponzevera, E., Borges, A., Darchambeau, F., De Deckker, P., Lambert, T., Monin, L., Toucanne, S., and André, L., 2018, The silicon isotopic composition of fine-grained river sediments and its relation to climate and lithology: Geochimica et Cosmochimica Acta, v. 229, p. 147-161, https://doi.org/10.1016/j.gca.2018.03.015

Behrens, R., Wirth, R., and von Blanckenburg, F., in press, Rate limitations of nano-scale weathering front advance in the slow-eroding Sri Lankan Highlands: Geochimica et Cosmochimica Acta.

Behrens, R., Bouchez, J., Schuessler, J. A., Dultz, S., Hewawasam, T., and von Blanckenburg, F., 2015, Mineralogical transformations set slow weathering rates in low-porosity metamorphic bedrock on mountain slopes in a tropical climate: Chemical Geology, v. 411, p. 283-298, https://doi.org/10.1016/ j.chemgeo.2015.07.008

Bern, C. R., Brzezinski, M. A., Beucher, C., Ziegler, K., and Chadwick, O. A., 2010, Weathering, dust, and biocycling effects on soil silicon isotope ratios: Geochimica et Cosmochimica Acta, v. 74, n. 3, p. 876889, https://doi.org/10.1016/j.gca.2009.10.046

Biscaye, P. E., 1965, Mineralogy and sedimentation of recent deep-sea clay in the Atlantic Ocean and adjacent seas and oceans: GSA Bulletin, v. 76, n. 7, p. 803-832, https://doi.org/10.1130/00167606(1965)76[803:MASORD]2.0.CO;2

Bouchez, J., von Blanckenburg, F., and Schuessler, J. A., 2013, Modeling novel stable isotope ratios in the weathering zone: American Journal of Science, v. 313, n. 4, p. 267-308, https://doi.org/10.2475/04 .2013 .01

Bouchez, J., Gaillardet, J., and von Blanckenburg, F., 2014, Weathering intensity in lowland river basins: From the Andes to the Amazon Mouth: Procedia Earth and Planetary Science, v. 10, p. 280-286, https://doi.org/10.1016/j.proeps.2014.08.063

Brantley, S. L., Liermann, L. J., Guynn, R. L., Anbar, A., Icopini, G. A., and Barling, J., 2004, Fe isotopic fractionation during mineral dissolution with and without bacteria: Geochimica et Cosmochimica Acta, v. 68, n. 15, p. 3189-3204, https://doi.org/10.1016/j.gca.2004.01.023

Brantley, S. L., Goldhaber, M. B., and Ragnarsdottir, K. V., 2007, Crossing disciplines and scales to understand the critical zone: Elements, v. 3, n. 5, p. 307-314, https://doi.org/10.2113/gselements.3.5.307

Burton, K. W., and O'Nions, R. K., 1990, The timescale and mechanism of granulite formation at Kurunegala, Sri Lanka: Contributions to Mineralogy and Petrology, v. 106, p. 66-89, https://doi.org/ 10.1007/BF00306409

Cardinal, D., Alleman, L. Y., de Jong, J., Ziegler, K., and André, L., 2003, Isotopic composition of silicon measured by multicollector plasma source mass spectrometry in dry plasma mode: Journal of Analytical Atomic Spectrometry, v. 18, p. 213-218, https://doi.org/10.1039/b210109b

Cary, L., Alexandre, A., Meunier, J. D., Boeglin, J. L., and Braun, J. J., 2005, Contribution of phytoliths to the suspended load of biogenic silica in the Nyong basin rivers (Cameroon): Biogeochemistry, v. 74, 101-114, https://doi.org/10.1007/s10533-004-2945-1

Churchman, G. J., and Lowe, D. J., 2012, Alteration, formation, and occurrence of minerals in soils, in Huang, P. M., LiY.and Sumner, M. E., editors, Handbook of Soil Sciences, 2nd edition. Vol. 1: Properties and Processes: Boca Raton, Florida, CRC press (Taylor and Francis), p. 20.1-20.72.

Coplen, T. B., 2011, Guidelines and recommended terms for expression of stable-isotope-ratio and gas-ratio measurement results: Rapid Communications in Mass Spectrometry, v. 25, n. 17, p. 2538-2560, https://doi.org/10.1002/rcm.5129

Cornelis, J. T., Delvaux, B., Cardinal, D., André, L., Ranger, J., and Opfergelt, S., 2010, Tracing mechanisms controlling the release of dissolved silicon in forest soil solutions using $\mathrm{Si}$ isotopes and $\mathrm{Ge} / \mathrm{Si}$ ratios: Geochimica et Cosmochimica Acta, v. 74, n. 14, p. 3913-3924, https://doi.org/10.1016/j.gca.2010.04.056

Cornelis, J.-T., Weis, D., Lavkulich, L., Vermeire, M.-L., Delvaux, B., and Barling, J., 2014, Silicon isotopes record dissolution and re-precipitation of pedogenic clay minerals in a podzolic soil chronosequence: Geoderma, v. 235-236, p. 19-29, https://doi.org/10.1016/j.geoderma.2014.06.023

Dahlgren, R. A., Boettinger, J. L., Huntington, G. L., and Amundson, R. G., 1997, Soil development along an elevational transect in the western Sierra Nevada, California: Geoderma, v. 78, n. 3-4, p. 207-236, https://doi.org/10.1016/S0016-7061(97)00034-7

De La Rocha, C. L., Brzezinski, M. A., and DeNiro, M. J., 2000, A first look at the distribution of the stable isotopes of silicon in natural waters: Geochimica et Cosmochimica Acta, v. 64, n. 14, p. 2467-2477, https://doi.org/10.1016/S0016-7037(00)00373-2

Dellinger, M., Bouchez, J., Gaillardet, J., Faure, L., and Moureau, J., 2017, Tracing weathering regimes using the lithium isotope composition of detrital sediments: Geology, v. 45, n. 5, p. 411-414, https:// doi.org/10.1130/G38671.1

Delstanche, S., Opfergelt, S., Cardinal, D., Elsass, F., André, L., and Delvaux, B., 2009, Silicon isotopic fractionation during adsorption of aqueous monosilicic acid onto iron oxide: Geochimica et Cosmochimica Acta, v. 73, n. 4, p. 923-934, https://doi.org/10.1016/j.gca.2008.11.014 
Delvigne, C., Opfergelt, S., Cardinal, D., Delvaux, B., and André, L., 2009, Distinct silicon and germanium pathways in the soil-plant system: Evidence from banana and horsetail: Journal of Geophysical Research-Biogeosciences, v. 114, n. G2, p. 11, https://doi.org/10.1029/2008JG000899

Demarest, M. S., Brzezinski, M. A., and Beucher, C. P., 2009, Fractionation of silicon isotopes during biogenic silica dissolution: Geochimica et Cosmochimica Acta, v. 73, n. 19, p. 5572-5583, https://doi.org/ $10.1016 /$ j.gca.2009.06.019

DePaolo, D. J., 2011, Surface kinetic model for isotopic and trace element fractionation during precipitation of calcite from aqueous solutions: Geochimica et Cosmochimica Acta, v. 75, n. 4, p. 1039-1056, https://doi.org/10.1016/j.gca.2010.11.020

Ding, T. P., Ma, G. R., Shui, M. X., Wan, D. F., and Li, R. H., 2005, Silicon isotope study on rice plants from the Zhejiang province, China: Chemical Geology, v. 218, p. 41-50, https://doi.org/10.1016/j .chemgeo.2005.01.018

Ding, T. P., Tian, S. H., Sun, L., Wu, L. H., Zhou, J. X., and Chen, Z. Y., 2008a, Silicon isotope fractionation between rice plants and nutrient solution and its significance to the study of the silicon cycle: Geochimica et Cosmochimica Acta, v. 72, n. 23, p. 5600, https://doi.org/10.1016/j.gca.2008.09.006

Ding, T. P., Zhou, J. X., Wan, D. F., Chen, Z. Y., Wang, C. Y., and Zhang, F., 2008b, Silicon isotope fractionation in bamboo and its significance to the biogeochemical cycle of silicon: Geochimica et Cosmochimica Acta, v. 72, n. 5, p. 1381, https://doi.org/10.1016/j.gca.2008.01.008

Dixon, J. L., and von Blanckenburg, F., 2012, Soils as pacemakers and limiters of global silicate weathering: Comptes Rendus Geoscience, v. 344, n. 11-12, p. 597-609, https://doi.org/10.1016/j.crte.2012.10.012

Dixon, J. L., Heimsath, A. M., and Amundson, R., 2009, The critical role of climate and saprolite weathering in landscape evolution: Earth Surface Processes and Landforms, v. 34, n. 11, p. 1507-1521, https://doi .org/10.1002/esp.1836

Dixon, J. L., Hartshorn, A. S., Heimsath, A. M., DiBiase, R. A., and Whipple, K. X., 2012, Chemical weathering response to tectonic forcing: A soils perspective from the San Gabriel Mountains, California: Earth and Planetary Science Letters, v. 323-324, p. 40-49, https://doi.org/10.1016/j.epsl.2012.01.010

Druhan, J. L., Brown, S. T., and Huber, C., 2015, Isotopic Gradients Across Fluid-Mineral Boundaries: Reviews in Mineralogy and Geochemistry, v. 80, n. 1, p. 355-391, https://doi.org/10.2138/rmg.2015 80.11

Dupuis, R., Benoit, M., Nardin, E., and Méheut, M., 2015, Fractionation of silicon isotopes in liquids: The importance of configurational disorder: Chemical Geology, v. 396, p. 239-254, https://doi.org/10 $.1016 /$ j.chemgeo.2014.12.027

Egli, M., Mirabella, A., and Fitze, P., 2001, Clay mineral formation in soils of two different chronosequences in the Swiss Alps: Geoderma, v. 104, n. 1-2, p. 145-175, https://doi.org/10.1016/S00167061(01)00079-9

Egli, M., Mirabella, A., and Sartori, G., 2008, The role of climate and vegetation in weathering and clay mineral formation in late Quaternary soils of the Swiss and Italian Alps: Geomorphology, v. 102, n. 3-4, p. 307-324, https://doi.org/10.1016/j.geomorph.2008.04.001

Engstrom, E., Rodushkin, I., Ingri, J., Baxter, D. C., Ecke, F., Osterlund, H., and Ohlander, B., 2010, Temporal isotopic variations of dissolved silicon in a pristine boreal river: Geochimica et Cosmochimica Acta, v. 271, n. 3-4, p. 142-152, https://doi.org/10.1016/j.chemgeo.2010.01.005

Ferrier, K. L., Kirchner, J. W., Riebe, C. S., and Finkel, R. C., 2010, Mineral-specific chemical weathering rates over millennial timescales: Measurements at Rio Icacos, Puerto Rico: Chemical Geology, v. 277, n. 1-2, p. 101-114, https://doi.org/10.1016/j.chemgeo.2010.07.013

Frick, D. A., Schuessler, J. A., and von Blanckenburg, F., 2016, Development of routines for simultaneous in situ chemical composition and stable $\mathrm{Si}$ isotope ratio analysis by femtosecond laser ablation inductively coupled plasma mass spectrometry: Analytica Chimica Acta, v. 938, p. 33-43, https://doi.org/10.1016/ j.aca.2016.08.029

Frick, D. A., Remus, R., Sommer, M., Augustin, J., Kaczorek, D., and von Blanckenburg, F., 2020, Silicon uptake and isotope fractionation dynamics by crop species: Biogeosciences, v. 17, n. 24, p. 6475-6490, https://doi.org/10.5194/bg-17-6475-2020

Frings, P. J., 2019, Palaeoweathering: How Do Weathering Rates Vary with Climate?: Elements, v. 15, n. 4 , p. 259-265, https://doi.org/10.2138/gselements.15.4.259

Frings, P. J., and Buss, H. L., 2019, The central role of weathering in the geosciences: Elements, v. 15, n. 4, p. 229-234, https://doi.org/10.2138/gselements.15.4.229

Frings, P. J., De La Rocha, C., Struyf, E., van Pelt, D., Schoelynck, J., Hudson, M. M., Gondwe, M. J., Wolski, P., Mosimane, K., Gray, W., Schaller, J., and Conley, D. J., 2014, Tracing silicon cycling in the Okavango Delta, a sub-tropical flood-pulse wetland using silicon isotopes: Geochimica et Cosmochimica Acta, v. 142, p. 132-148, https://doi.org/10.1016/j.gca.2014.07.007

Frings, P. J., Clymans, W., Fontorbe, G., Gray, W., Chakrapani, G. J., Conley, D. J., and De La Rocha, C., 2015, Silicate weathering in the Ganges alluvial plain: Earth and Planetary Science Letters, v. 427, p. 136-148, https://doi.org/10.1016/j.epsl.2015.06.049

Frings, P. J., Fontorbe, G., Clymans, W., De La Rocha, C. L., and Conley, D. J., 2016, The continental Si cycle and its impact on the ocean Si isotope budget: Chemical Geology, v. 425, p. 12-36, https://doi.org/10 $.1016 /$ j.chemgeo.2016.01.020

Frings, P. J., Oelze, M., Schubring, F., Frick, D. A., and von Blanckenburg, F., 2021a, Geochemical data on silicon isotope and Ge/Si ratios along a global erodosequence: GFZ Data Services, https://doi.org/10 $.5880 /$ GFZ.3.3.2021.003

Frings, P. J., Schubring, F., Oelze, M., and von Blanckenburg, F., 2021b, Quantifying biotic and abiotic Si fluxes in the Critical Zone with $\mathrm{Ge} / \mathrm{Si}$ ratios along a gradient of erosion rates: American Journal of Science, v. 321, n. 8, p. 1204-1245, https://doi.org10.2475/08.2021.03 
Fujii, T., Pringle, E. A., Chaussidon, M., and Moynier, F., 2015, Isotope fractionation of Si in protonation/ deprotonation reaction of silicic acid: A new pH proxy: Geochimica et Cosmochimica Acta, v. 168, p. 193-205, https://doi.org/10.1016/j.gca.2015.07.003

Geilert, S., Vroon, P. Z., Roerdink, D. L., Cappellen, P. V., and van Bergen, M. J., 2014, Silicon isotope fractionation during abiotic silica precipitation at low temperatures: Inferences from flow-through experiments: Geochimica et Cosmochimica Acta, v. 142, p. 95-114, https://doi.org/10.1016/j.gca.2014.07 .003

Georg, R. B., Reynolds, B. C., Frank, M., and Halliday, A. N., 2006, New sample preparation techniques for the determination of $\mathrm{Si}$ isotopic compositions using MC-ICPMS: Chemical Geology, v. 235, n. 1-2, p. 95-104, https://doi.org/10.1016/j.chemgeo.2006.06.006

Georg, R. B., Zhu, C., Reynolds, B. C., and Halliday, A. N., 2009, Stable silicon isotopes of groundwater, feldspars, and clay coatings in the Navajo Sandstone aquifer, Black Mesa, Arizona, USA: Geochimica et Cosmochimica Acta, v. 73, n. 8, p. 2229-2241, https://doi.org/10.1016/j.gca.2009.02.005

Georgiadis, A., Sauer, D., Herrmann, L., Breuer, J., Zarei, M., and Stahr, K., 2013, Development of a method for sequential Si extraction from soils: Geoderma, v. 209-210, p. 251-261, https://doi.org/10 .1016/j.geoderma.2013.06.023

Gromet, L. P., and Silver, L. T., 1983, Rare earth element distributions among minerals in a granodiorite and their petrogenetic implications: Geochimica et Cosmochimica Acta, v. 47, n. 5, p. 925-939, https://doi.org/10.1016/0016-7037(83)90158-8

Hahm, W. J., Riebe, C. S., Lukens, C. E., and Araki, S., 2014, Bedrock composition regulates mountain ecosystems and landscape evolution: Proceedings of the National Academy of Sciences of the United States of America, v. 111, n. 9, 3338-3343, https://doi.org/10.1073/pnas.1315667111

Harlavan, Y., Erel, Y., and Blum, J. D., 1998, Systematic changes in lead isotopic composition with soil age in glacial granitic terrains: Geochimica et Cosmochimica Acta, v. 62, n. 1, p. 33-46, https://doi.org/10 .1016/S0016-7037(97)00328-1

He, H. T., and Liu, Y., 2015, Silicon isotope fractionation during the precipitation of quartz and the adsorption of $\mathrm{H}_{4} \mathrm{SiO}_{4(\mathrm{aq})}$ on $\mathrm{Fe}(\mathrm{III})$-oxyhydroxide surfaces: Chinese Journal of Geochemistry, v. 34, p. 459468, https://doi.org/10.1007/s11631-015-0068-0

He, H. T., Zhang, S., Zhu, C., and Liu, Y., 2016, Equilibrium and kinetic Si isotope fractionation factors and their implications for $\mathrm{Si}$ isotope distributions in the Earth's surface environments: Acta Geochimica, v. 35, p. 15-24, https://doi.org/10.1007/s11631-015-0079-x

Hellmann, R., Wirth, R., Daval, D., Barnes, J.-P., Penisson, J.-M., Tisserand, D., Epicier, T., Florin, B., and Hervig, R. L., 2012, Unifying natural and laboratory chemical weathering with interfacial dissolutionreprecipitation: A study based on the nanometer-scale chemistry of fluid-silicate interfaces: Chemical Geology, v. 294-295, p. 203-216, https://doi.org/10.1016/j.chemgeo.2011.12.002

Hewawasam, T., von Blanckenburg, F., Schaller, M., and Kubik, P., 2003, Increase of human over natural erosion rates in tropical highlands constrained by cosmogenic nuclides: Geology, v. 31, n. 7, p. 597600, https:/ / doi.org/10.1130/0091-7613(2003)031<0597:IOHONE > 2.0.CO;2

Hewawasam, T., von Blanckenburg, F., Bouchez, J., Dixon, J. L., Schuessler, J. A., and Maekeler, R., 2013, Slow advance of the weathering front during deep, supply-limited saprolite formation in the tropical Highlands of Sri Lanka: Geochimica et Cosmochimica Acta, v. 118, p. 202-230, https://doi.org/10 $.1016 /$ j.gca.2013.05.006

Hodson, M. J., Parker, A. G., Leng, M. J., and Sloane, H. J., 2008, Silicon, oxygen and carbon isotope composition of wheat (Triticum aestivum L.) phytoliths: Implications for palaeoecology and archaeology: Journal of Quaternary Science, v. 23, n. 4, p. 331-339, https://doi.org/10.1002/jqs.1176

Hughes, H. J., Bouillon, S., André, L., and Cardinal, D., 2012, The effects of weathering variability and anthropogenic pressures upon silicon cycling in an intertropical watershed (Tana River, Kenya): Chemical Geology, v. 308-309, p. 18-25, https://doi.org/10.1016/j.chemgeo.2012.03.016

Hughes, H. J., Sondag, F., Santos, R. V., André, L., and Cardinal, D., 2013, The riverine silicon isotope composition of the Amazon Basin: Geochimica et Cosmochimica Acta, v. 121, p. 637-651, https://doi.org/ 10.1016/j.gca.2013.07.040

Hunsaker, C. T., and Neary, D. G., 2012, Sediment loads and erosion in forest headwater streams of the Sierra Nevada, California, in Revisiting Experimental Catchemnt Studies in Forest Hydrology: Wallingford, United Kingdom, Proceedings of a workshop for the International Association of Hydrological Sciences, General Assembly in Melbourne, June-July 2011, p. 195-204.

Jochum, K. P., Nohl, U., Herwig, K., Lammel, E., Stoll, B., and Hofmann, A. W., 2005, GeoReM: A new geochemical database for reference materials and isotopic standards: Geostandards and Geoanalytical Research, v. 29, n. 3, p. 333-338, https://doi.org/10.1111/j.1751-908X.2005.tb00904.x

Jochum, K. P., Weis, U., Stoll, B., Kuzmin, D., Yang, Q., Raczek, I., Jacob, D. E., Stracke, A., Birbaum, K., Frick, D. A., Günther, D., and Enzweiler, J., 2011, Determination of reference values for NIST SRM 610-617 glasses following ISO guidelines: Geostandards and Geoanalytical Research, v. 35, n. 4, p. 397-429, https://doi.org/10.1111/j.1751-908X.2011.00120.x

Joe-Wong, C., Weaver, K. L., Brown, S. T., and Maher, K., 2019, Thermodynamic controls on redox-driven kinetic stable isotope fractionation: Geochemical Perspectives Letters, v. 10, p. 20-25, https://doi.org/ 10.7185/geochemlet.1909

Johnson, D. W., Hunsaker, C. T., Glass, D. W., Rau, B. M., and Roath, B. A., 2011, Carbon and nutrient contents in soils from the Kings River Experimental Watersheds, Sierra Nevada Mountains, California: Geoderma, v. 160, n. 3-4, p. 490-502, https://doi.org/10.1016/j.geoderma.2010.10.019

Kiczka, M., Wiederhold, J. G., Frommer, J., Kraemer, S. M., Bourdon, B., and Kretzschmar, R., 2010, Iron isotope fractionation during proton- and ligand-promoted dissolution of primary phyllosilicates: Geochimica et Cosmochimica Acta, v. 74, n. 11, p. 3112-3128, https://doi.org/10.1016/j.gca.2010.02 .018 
Larsen, I. J., Almond, P. C., Eger, A., Stone, J. O., Montgomery, D. R., and Malcolm, B., 2014, Rapid Soil Production and Weathering in the Southern Alps, New Zealand: Science, v. 343, n. 6171, p. 637-640, https://doi.org/10.1126/science.1244908

Liu, F., Hunsaker, C., and Bales, R. C., 2013, Controls of streamflow generation in small catchments across the snow-rain transition in the Southern Sierra Nevada: California: Hydrological Processes, v. 27, n. 14, p. 1959-1972, https://doi.org/10.1002/hyp.9304

Liu, Y., Hu, Z., Gao, S., Günther, D., Xu, J., Gao, C., and Chen, H., 2008, In situ analysis of major and trace elements of anhydrous minerals by LA-ICP-MS without applying an internal standard: Chemical Geology, v. 257, n. 1-2, p. 34-43, https://doi.org/10.1016/j.chemgeo.2008.08.004

Ma, J. F., and Yamaji, N., 2008, Functions and transport of silicon in plants: Cellular and Molecular Life Sciences, v. 65, p. 3049-3057, https://doi.org/10.1007/s00018-008-7580-x

Maher, K., and Chamberlain, C. P., 2014, Hydrologic regulation of chemical weathering and the geologic carbon cycle: Science, v. 343, n. 6178, p. 1502-1504, https://doi.org/10.1126/science.1250770

Méheut, M., and Schauble, E. A., 2014, Silicon isotope fractionation in silicate minerals: Insights from firstprinciples models of phyllosilicates, albite and pyrope: Geochimica et Cosmochimica Acta, v. 134 p. 137-154, https://doi.org/10.1016/j.gca.2014.02.014

Méheut, M., Lazzeri, M., Balan, E., and Mauri, F., 2009, Structural control over equilibrium silicon and oxygen isotopic fractionation: A first-principles density-functional theory study: Chemical Geology, v. 258, n. 1-2, p. 28-37, https://doi.org/10.1016/j.chemgeo.2008.06.051

Nesbitt, H. W., and Young, G. M., 1982, Early Proterozoic climates and plate motions inferred from major element chemistry of lutites: Nature, v. 299, p. 715-717, https://doi.org/10.1038/299715a0

Nielsen, L. C., DePaolo, D. J., and De Yoreo, J. J., 2012, Self-consistent ion-by-ion growth model for kinetic isotopic fractionation during calcite precipitation: Geochimica et Cosmochimica Acta, v. 86, p. 166181, https://doi.org/10.1016/j.gca.2012.02.009

Norton, K. P., ms, 2008, Response of the landscape in the Swiss Alps to the late Glacial to Holocene climate transition: Hannover, Germany, Gottfried Wilhelm Leibniz Universität Hannover, Ph. D. thesis.

Norton, K. P., and von Blanckenburg, F., 2010, Silicate weathering of soil-mantled slopes in an active Alpine landscape: Geochimica et Cosmochimica Acta, v. 74, n. 18, p. 5243-5258, https://doi.org/10.1016/j .gca.2010.06.019

Norton, K. P., von Blanckenburg, F., and Kubik, P. W., 2010, Cosmogenic nuclide-derived rates of diffusive and episodic erosion in the glacially sculpted upper Rhone Valley, Swiss Alps: Earth Surface Processes and Landforms, v. 35, n. 6, p. 651-662, https://doi.org/10.1002/esp.1961

Oelze, M., ms, 2015, Silicon isotope fractionation at low temperatures in the presence of Aluminum: An experimental approach and application to different weathering regimes: Berlin, Germany, Freie Universität Berlin, Ph. D. thesis, 177 p.

Oelze, M., von Blanckenburg, F., Hoellen, D., Dietzel, M., and Bouchez, J., 2014, Si stable isotope fractionation during adsorption and the competition between kinetic and equilibrium isotope fractionation: Implications for weathering systems: Chemical Geology, v. 380, p. 161-171, https://doi.org/10.1016/j .chemgeo.2014.04.027

Oelze, M., von Blanckenburg, F., Bouchez, J., Hoellen, D., and Dietzel, M., 2015, The effect of Al on Si isotope fractionation investigated by silica precipitation experiments: Chemical Geology, v. 397, p. 94105, https://doi.org/10.1016/j.chemgeo.2015.01.002

Oelze, M., Schuessler, J. A., and von Blanckenburg, F., 2016, Mass bias stabilization by Mg doping for Si stable isotope analysis by MC-ICP-MS: Journal of Analytical Atomic Spectrometry, v. 31, n. 10, p. 2094 2100, https://doi.org/10.1039/C6JÄ00218H

Opfergelt, S., and Delmelle, P., 2012, Silicon isotopes and continental weathering processes: Assessing controls on Si transfer to the ocean: Comptes Rendus Geoscience, v. 344, n. 11-12, p. 723-738, https:// doi.org/10.1016/j.crte.2012.09.006

Opfergelt, S., Cardinal, D., Henriet, C., Draye, X., André, L., and Delvaux, B., 2006, Silicon isotopic fractionation by banana (Musa spp.) grown in a continuous nutrient flow device: Plant and Soil, v. 285, p. 333-345, https://doi.org/10.1007/s11104-006-9019-1

Opfergelt, S., de Bournonville, G., Cardinal, D., André, L., Delstanche, S., and Delvaux, B., 2009, Impact of soil weathering degree on silicon isotopic fractionation during adsorption onto iron oxides in basaltic ash soils, Cameroon: Geochimica et Cosmochimica Acta, v. 73, n. 24, p. 7226-7240, https://doi.org/10 .1016/j.gca.2009.09.003

Opfergelt, S., Cardinal, D., André, L., Delvigne, C., Bremond, L., and Delvaux, B., 2010, Variations of $\delta^{30} \mathrm{Si}$ and $\mathrm{Ge} / \mathrm{Si}$ with weathering and biogenic input in tropical basaltic ash soils under monoculture: Geochimica et Cosmochimica Acta, v. 74, n. 1, p. 225-240, https://doi.org/10.1016/j.gca.2009.09.025

Opfergelt, S., Georg, R. B., Delvaux, B., Cabidoche, Y. M., Burton, K. W., and Halliday, A. N., 2012, Silicon isotopes and the tracing of desilication in volcanic soil weathering sequences, Guadeloupe: Chemical Geology, v. 326-327, p. 113-122, https://doi.org/10.1016/j.chemgeo.2012.07.032

Opfergelt, S., Williams, H. M., Cornelis, J. T., Guicharnaud, R. A., Georg, R. B., Siebert, C., Gislason, S. R., Halliday, A. N., and Burton, K. W., 2017, Iron and silicon isotope behaviour accompanying weathering in Icelandic soils, and the implications for iron export from peatlands: Geochimica et Cosmochimica Acta, v. 217, p. 273-291, https://doi.org/10.1016/j.gca.2017.08.033

Pokharel, R., Gerrits, R., Schuessler, J. A., and von Blanckenburg, F., 2019, Mechanisms of olivine dissolution by rock-inhabiting fungi explored using magnesium stable isotopes: Chemical Geology, v. 525, p. 18-27, https://doi.org/10.1016/j.chemgeo.2019.07.001

Price, J. R., Velbel, M. A., and Patino, L. C., 2005, Rates and time scales of clay-mineral formation by weathering in saprolitic regoliths of the southern Appalachians from geochemical mass balance: GSA Bulletin, v. 117, n. 5-6, p. 783-794, https://doi.org/10.1130/B25547.1 
Riotte, J., Meunier, J.-D., Zambardi, T., Audry, S., Barboni, D., Anupama, K., Prasad, S., Chmeleff, J., Poitrasson, F., Sekhar, M., and Braun, J.-J., 2018, Processes controlling silicon isotopic fractionation in a forested tropical watershed: Mule Hole Critical Zone Observatory (Southern India): Geochimica et Cosmochimica Acta, v. 228, p. 301-319, https://doi.org/10.1016/j.gca.2018.02.046

Roerdink, D. L., van den Boorn, S. H., Geilert, S., Vroon, P. Z., and van Bergen, M. J., 2015, Experimental constraints on kinetic and equilibrium silicon isotope fractionation during the formation of non-biogenic chert deposits: Chemical Geology, v. 402, p. 40-51, https://doi.org/10.1016/j.chemgeo.2015.02 .038

Rudnick, R. L., and Gao, S., 2003, 3.01 - Composition of the Continental Crust , in Rudnick, R. L., editor, The Crust: Treatise on Geochemistry, v. 3, p. 1-64, https://doi.org/10.1016/B0-08-043751-6/03016-4

Savage, P. S., Georg, R. B., Williams, H. M., Burton, K. W., and Halliday, A. N., 2011, Silicon isotope fractionation during magmatic differentiation: Geochimica et Cosmochimica Acta, v. 75, n. 20, p. 6124-6139, https://doi.org/10.1016/j.gca.2011.07.043

Savage, P. S., Georg, R. B., Williams, H. M., Turner, S., Halliday, A. N., and Chappell, B. W., 2012, The silicon isotope composition of granites: Geochimica et Cosmochimica Acta, v. 92, p. 184-202, https://doi .org/10.1016/j.gca.2012.06.017

Savage, P. S., Georg, R. B., Williams, H. M., and Halliday, A. N., 2013, The silicon isotope composition of the upper continental crust: Geochimica et Cosmochimica Acta, v. 109, p. 384-399, https://doi.org/ 10.1016/j.gca.2013.02.004

Savage, P. S., Armytage, R. M. G., Georg, R. B., and Halliday, A. N., 2014, High temperature silicon isotope geochemistry: Lithos, v. 190-191, p. 500-519, https://doi.org/10.1016/j.lithos.2014.01.003

Schuessler, J. A., and von Blanckenburg, F., 2014, Testing the limits of micro-scale analyses of Si stable isotopes by femtosecond laser ablation multicollector inductively coupled plasma mass spectrometry with application to rock weathering: Spectrochimica Acta Part B: Atomic Spectroscopy, v. 98, p. 1-18, https://doi.org/10.1016/j.sab.2014.05.002

Schuessler, J. A., von Blanckenburg, F., Bouchez, J., Uhlig, D., and Hewawasam, T., 2018, Nutrient cycling in a tropical montane rainforest under a supply-limited weathering regime traced by elemental mass balances and $\mathrm{Mg}$ stable isotopes: Chemical Geology, v. 497, p. 74-87, https://doi.org/10.1016/j .chemgeo.2018.08.024

Stallard, R. F., and Edmond, J. M., 1983, Geochemistry of the Amazon: 2. The influence of geology and weathering environment on the dissolved load: Journal of Geophysical Research: Oceans, v. 88, n. C14, p. 9671-9688, https://doi.org/10.1029/JC088iC14p09671

Stamm, F. M., Zambardi, T., Chmeleff, J., Schott, J., von Blanckenburg, F., and Oelkers, E. H., 2019, The experimental determination of equilibrium $\mathrm{Si}$ isotope fractionation factors among $\mathrm{H}_{4} \mathrm{SiO}_{4}, \mathrm{H}_{3} \mathrm{SiO}_{4}{ }^{-}$and amorphous silica $\left(\mathrm{SiO}_{2} \cdot 0.32 \mathrm{H}_{2} \mathrm{O}\right)$ at 25 and $75^{\circ} \mathrm{C}$ using the three-isotope method: Geochimica et Cosmochimica Acta, v. 255, p. 49-68, https://doi.org/10.1016/j.gca.2019.03.035

Steinhoefel, G., Breuer, J., von Blanckenburg, F., Horn, I., Kaczorek, D., and Sommer, M., 2011, Micrometer silicon isotope diagnostics of soils by UV femtosecond laser ablation: Chemical Geology, v. 286, n. 3-4, p. 280-289, https://doi.org/10.1016/j.chemgeo.2011.05.013

Steinhoefel, G., Breuer, J., von Blanckenburg, F., Horn, I., and Sommer, M., 2017, The dynamics of Si cycling during weathering in two small catchments in the Black Forest (Germany) traced by $\mathrm{Si}$ isotopes: Chemical Geology, v. 466, p. 389-402, https://doi.org/10.1016/j.chemgeo.2017.06.026

Sun, L., Wu, L. H., Ding, T. P., and Tian, S. H., 2008, Silicon isotope fractionation in rice plants, an experimental study on rice growth under hydroponic conditions: Plant and Soil, v. 304, p. 291-300, https:// doi.org/10.1007/s11104-008-9552-1

Sun, X., Olofsson, M., Andersson, P. S., Fry, B., Legrand, C., Humborg, C., and Mörth, C.-M., 2014, Effects of growth and dissolution on the fractionation of silicon isotopes by estuarine diatoms: Geochimica et Cosmochimica Acta, v. 130, p. 156-166, https://doi.org/10.1016/j.gca.2014.01.024

Sun, Y., Wu, L., Li, X., Sun, L., Gao, J., and Ding, T., 2016a, Silicon isotope fractionation in rice and cucumber plants over a life cycle: Laboratory studies at different external silicon concentrations: Journal of Geophysical Research: Biogeosciences, v. 121, n. 11, p. 2829-2841, https://doi.org/10.1002/ 2016JG003443

Sun, Y., Wu, L.-h., and Li, X.-y., 2016b, Experimental determination of silicon isotope fractionation in rice: PLoS ONE, v. 11, p. e0168970, https://doi.org/10.1371/journal.pone.0168970

Sun, Y., Wu, L., Li, X., Sun, L., Gao, J., Ding, T., and Zhu, Y., 2017, Silicon isotope fractionation in maize and its biogeochemical significance: Analytical Letters, v. 50, n. 15, p. 2475-2490, https://doi.org/10 $.1080 / 00032719.2017 .1295460$

Thiry, M., 2000, Palaeoclimatic interpretation of clay minerals in marine deposits: An outlook from the continental origin: Earth-Science Reviews, v. 49, n. 1-4, p. 201-221, https://doi.org/10.1016/S00128252(99)00054-9

Ugray, Z., Lasdon, L., Plummer, J., Glover, F., Kelly, J., and Martí, R., 2007, Scatter search and local NLP solvers: A multistart framework for global optimization: INFORMS Journal on Computing, v. 19, n. 3, p. 328-340, https://doi.org/10.1287/ijoc.1060.0175

Uhlig, D., Schuessler, J. A., Bouchez, J., Dixon, J. L., and von Blanckenburg, F., 2017, Quantifying nutrient uptake as driver of rock weathering in forest ecosystems by magnesium stable isotopes: Biogeosciences, v. 14, n. 2, p. 3111-3128, https://doi.org/10.5194/bg-14-3111-2017

Velbel, M. A., and Price, J. R., 2007, Solute geochemical mass-balances and mineral weathering rates in small watersheds: Methodology, recent advances, and future directions: Applied Geochemistry, v. 22, n. 8, p. 1682-1700, https://doi.org/10.1016/j.apgeochem.2007.03.029

von Blanckenburg, F., Schuessler, J. A., Bouchez, J., Frings, P. J., Uhlig, D., Oelze, M., Frick, D. A., Hewawasam, T., Dixon, J., and Norton, K., 2021, Rock weathering and nutrient cycling along an 
erodosequence: American Journal of Science, v. 321, n. 8, p. 1111-1163, https://doi.org/10.2475/08 .2021 .01

Weiss, D. J., Boye, K., Caldelas, C., and Fendorf, S., 2014, Zinc isotope fractionation during early dissolution of biotite granite: Soil Science Society of America Journal, v. 78, n. 1, p. 171-179, https://doi.org/10 $.2136 /$ sssaj2012.0426

West, A. J., Galy, A., and Bickle, M., 2005, Tectonic and climatic controls on silicate weathering: Earth and Planetary Science Letters, v. 235, n. 1-2, p. 211-228, https://doi.org/10.1016/j.epsl.2005.03.020

Wetzel, F., de Souza, G. F., and Reynolds, B. C., 2014, What controls silicon isotope fractionation during dissolution of diatom opal?: Geochimica et Cosmochimica Acta, v. 131, p. 128-137, https://doi.org/10 $.1016 /$ j.gca.2014.01.028

White, A. F., Vivit, D. V., Schulz, M. S., Bullen, T. D., Evett, R. R., and Aagarwal, J., 2012, Biogenic and pedogenic controls on $\mathrm{Si}$ distributions and cycling in grasslands of the Santa Cruz soil chronosequence, California: Geochimica et Cosmochimica Acta, v. 94, p. 72-94, https://doi.org/10.1016/j.gca.2012.06 .009

Wimpenny, J., Gíslason, S. R., James, R. H., Gannoun, A., Pogge Von Strandmann, P. A. E., and Burton, $\mathrm{K}$. W., 2010, The behaviour of $\mathrm{Li}$ and $\mathrm{Mg}$ isotopes during primary phase dissolution and secondary mineral formation in basalt: Geochimica et Cosmochimica Acta, v. 74, n. 18, p. 5259-5279, https://doi .org/10.1016/j.gca.2010.06.028

Yang, J.-L., and Zhang, G.-L., 2019, Si cycling and isotope fractionation: Implications on weathering and soil formation processes in a typical subtropical area: Geoderma, v. 337, p. 479-490, https://doi.org/10 .1016/j.geoderma.2018.09.047

Yang, L., and Steefel, C. I., 2008, Kaolinite dissolution and precipitation kinetics at $22^{\circ} \mathrm{C}$ and $\mathrm{pH} 4$ Geochimica et Cosmochimica Acta, v. 72, n. 1, p. 99-116, https://doi.org/10.1016/j.gca.2007.10.011

Zambardi, T., and Poitrasson, F., 2011, Precise determination of silicon isotopes in silicate rock reference materials by MC-ICP-MS: Geostandards and Geoanalytical Research, v. 35, n. 1, p. 89-99, https://doi .org/10.1111/j.1751-908X.2010.00067.x

Ziegler, K., Chadwick, O. A., Brzezinski, M. A., and Kelly, E. F., 2005a, Natural variations of $\delta^{30}$ Si ratios during progressive basalt weathering, Hawaiian Islands: Geochimica et Cosmochimica Acta, v. 69, n. 19 p. 4597-4610, https://doi.org/10.1016/j.gca.2005.05.008

Ziegler, K., Chadwick, O. A., White, A. F., and Brzezinski, M. A., 2005b, $\delta^{30}$ Si systematics in a granitic saprolite, Puerto Rico: Geology, v. 33, n. 10, p. 817-820, https://doi.org/10.1130/G21707.1 